\title{
Abrogated Freud-1/Cc2d1a Repression of 5-HT1A Autoreceptors Induces Fluoxetine-Resistant Anxiety/ Depression-Like Behavior
}

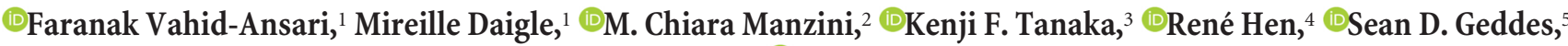

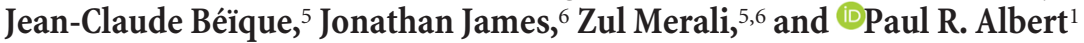 \\ ${ }^{1}$ Ottawa Hospital Research Institute (Neuroscience), University of Ottawa Brain and Mind Research Institute, Ottawa, Ontario K1H-8M5, Canada, \\ ${ }^{2}$ Department of Pharmacology and Physiology, George Washington University School of Medicine and Health Sciences, Washington, DC 20037, \\ ${ }^{3}$ Department of Neuropsychiatry, Keio University School of Medicine, Tokyo, 160-8582, Japan, ${ }^{4}$ Department of Psychiatry, Columbia University Medical \\ Center and Research Foundation for Mental Hygiene, New York State Psychiatric Institute, New York, New York 10032, ${ }^{5}$ Department of Cellular and \\ Molecular Medicine, University of Ottawa Brain and Mind Research Institute, Ottawa K1H-8M5 Canada, and ${ }^{6}$ The Royal's Institute of Mental Health, \\ affiliated with the University of Ottawa, Ottawa, Ontario, K1Z-7K4 Canada
}

Freud-1/Cc2d1a represses the gene transcription of serotonin-1A (5-HT1A) autoreceptors, which negatively regulate 5-HT tone. To test the role of Freud-1 in vivo, we generated mice with adulthood conditional knock-out of Freud-1 in 5-HT neurons ( $c$ F1ko). In $c F 1 k o$ mice, 5-HT1A autoreceptor protein, binding and hypothermia response were increased, with reduced 5-HT content and neuronal activity in the dorsal raphe. The $c F 1 k o$ mice displayed increased anxiety- and depression-like behavior that was resistant to chronic antidepressant (fluoxetine) treatment. Using conditional Freud-1/5-HT1A double knock-out ( $c F 1 / 1 A d k o$ ) to disrupt both Freud-1 and 5-HT1A genes in 5-HT neurons, no increase in anxiety- or depression-like behavior was seen upon knock-out of Freud-1 on the 5-HT1A autoreceptornegative background; rather, a reduction in depression-like behavior emerged. These studies implicate transcriptional dysregulation of 5-HT1A autoreceptors by the repressor Freud-1 in anxiety and depression and provide a clinically relevant genetic model of antidepressant resistance. Targeting specific transcription factors, such as Freud-1, to restore transcriptional balance may augment response to antidepressant treatment.

Key words: 5-HT1A receptor; anxiety; major depression; raphe; repressor; serotonin

\section{Significance Statement}

Altered regulation of the 5-HT1A autoreceptor has been implicated in human anxiety, major depression, suicide, and resistance to antidepressants. This study uniquely identifies a single transcription factor, Freud-1, as crucial for 5-HT1A autoreceptor expression in vivo. Disruption of Freud-1 in serotonin neurons in mice links upregulation of 5-HT1A autoreceptors to anxiety/depression-like behavior and provides a new model of antidepressant resistance. Treatment strategies to reestablish transcriptional regulation of 5-HT1A autoreceptors could provide a more robust and sustained antidepressant response.

\section{Introduction}

Major depression and anxiety disorders are highly prevalent and often comorbid lifelong diseases (Kessler and Bromet,

\footnotetext{
Received June 15, 2017; revised Sept. 29, 2017; accepted 0ct. 10, 2017.

Author contributions:F.V.-A., S.D.G., J.-C.B., J.J., Z.M., and P.R.A. designed research;F.V.-A., M.D., S.D.G., and J.J. performed research; M.C.M., K.F.T., R.H., and P.R.A. contributed unpublished reagents/analytic tools; F.V.-A., M.D., S.D.G., J.-C.B., J.J., Z.M., and P.R.A. analyzed data; F.V.-A., M.C.M., R.H., S.D.G., J.-C.B., and P.R.A. wrote the paper.

This work was supported by Canadian Institutes for Health Research Grants MOP-115098 and MOP-123426 to P.R.A., and Canadian Partnership for Stroke Recovery trainee support to F.V.-A. These agencies had no role in the design of the study, collection, and analysis of data or decision to publish. We thank Dr. C. A. Walsh (Harvard University) for providing the (c2d1a (Freud-1 $)^{f f x / f l x}$ mice; Drs. Kate Nautiyal and Zoe Donaldson (Columbia University) for helpful discussions; and Dr. Diane C. Lagace and the University of Ottawa Behavioral Core for helpful advice and technical assistance.
}

2013; Whiteford et al., 2013) that involve reductions in the activity of monoaminergic systems, particularly the serotonin (5-HT) system (Jans et al., 2007; Krishnan and Nestler, 2008; Booij et al., 2015). The chronic course of depression and antidepressant action implicates long-term dysregulation of the 5-HT system. A critical node regulating 5 - $\mathrm{HT}$ activity is the 5 - $\mathrm{HT} 1 \mathrm{~A}$ receptor

\footnotetext{
The authors declare no competing financial interests.
}

Correspondence should be addressed to Dr. Paul R. Albert, Ottawa Hospital Research Institute (Neuroscience), University of Ottawa Brain and Mind Research Institute, 451 Smyth Road, Ottawa, Ontario K1H-8M5, Canada. E-mail: palbert@uottawa.ca.

DOI:10.1523/JNEUROSCI.1668-17.2017

Copyright $\odot 2017$ the authors $\quad 0270-6474 / 17 / 3711967-12 \$ 15.00 / 0$ 
gene (HTR1A), which is expressed as a somatodendritic autoreceptor to inhibit the firing of 5-HT neurons, and as a heteroreceptor at targets of the 5-HT system implicated in mood, emotion, stress response, and antidepressant action (Albert and Lemonde, 2004; Albert et al., 2014; Garcia-Garcia et al., 2014). Increases in 5-HT1A autoreceptors, which would tend to reduce 5-HT neurotransmission, are found in depressed and attempted suicide subjects and in depressed suicide postmortem tissue (Albert et al., 2011; Hesselgrave and Parsey, 2013; Sullivan et al., 2015), and the latency to respond to antidepressant treatment has been attributed in part to the time required to desensitize 5-HT1A autoreceptors (Albert and Lemonde, 2004; Blier and El Mansari, 2013). However, the transcriptional mechanisms that dictate long-term receptor expression and their roles in anxiety, depression, and response to antidepressants remain unclear.

The HTR1A gene contains a series of repressor elements upstream of the promoter that suppress its expression (Albert and Fiori, 2014). Within the repressor region, a strong dual repressor element binds to Freud-1/Cc2d1a, which represses HTR1A transcription in neuronal and non-neuronal cells (Ou et al., 2000, 2003; Lemonde et al., 2004a; Rogaeva and Albert, 2007). In adult mice, Freud-1 is coexpressed with 5-HT1A receptors throughout the brain (Ou et al., 2003). In the raphe, Freud-1 is coexpressed with 5-HT1A autoreceptors, unlike its homolog Freud-2/Cc2d1b, which is weakly detected in the raphe (Hadjighassem et al., 2009; Szewczyk et al., 2010). Knockdown of Freud-1 results in derepression of 5-HT1A transcription in raphe cells (Ou et al., 2003); we thus hypothesized that Freud-1 functions as a key repressor of 5-HT1A autoreceptor expression in vivo, that might affect 5-HT regulation, and depression and anxiety behavior. We have generated mice with knockout (KO) of Freud-1 in adult 5-HT neurons to address this hypothesis.

\section{Materials and Methods}

\section{Experimental design}

Mouse models. All animal studies were done in accordance with the University of Ottawa Animal Care Committee guidelines. Animals were maintained on a $12 \mathrm{~h}$ light/dark cycle (7:00 A.M. to 7:00 P.M.) with ad libitum access to food and water. Both sexes were used, and the proportion of male/female did not differ among groups; because no differences between male and female were observed in the tests conducted, the data were pooled. The Cc2d1a (Freud-1) flx/flx mice (Oaks et al., 2017) were crossed with TPH2-CreERT2 mice (stock \#016584, C57BL/6N background, Jackson ImmunoResearch Laboratories, https://www.jax.org/ strain/016584; RRID:IMSR_JAX:016584) to generate heterozygous TPH2CreERT2-Freud-1wt/flx mice, which were interbred to generate homozygous TPH2-CreERT2-Freud-1flx/flx (cF1ko) and TPH2-CreERT2-Freud-1wt/wt (WT) littermates (see Fig. 1A). At 8 weeks of age, mice were administered tamoxifen (Sigma, catalog \#T5648, $180 \mathrm{mg} / \mathrm{d}, \sim 3 \mathrm{mg} / \mathrm{kg}$, i.p.) once/d for 5 consecutive days to activate CreERT2-induced recombination. To detect Cre-induced recombination, $c F 1 k o$ mice were crossed into a ROSA26-flxSTOP-GFP C57BL/6J background (obtained from Dr. Diane Lagace, University of Ottawa). The TPH2-Cre-ERT2/Freud-1wt/flx were crossed with $f l x-1 A$ mice $(\mathrm{C} 57 \mathrm{BL} / 6 \times 129 \mathrm{~Sv} \times \mathrm{ROSA}$-Flpe background) (Szewczyk et al., 2014; Samuels et al., 2015) and bred to obtain TPH2CreERT2-Freud-1flx/flx/1Aflx/flx mice ( $c F 1 / 1 A d k o$ ) (see Fig. 1A). To obtain Freud-1 WT mice on the 5-HT1A autoKO background, cFreud-1wt/ $w t: 1 A w t / f l x$ were crossed with $c$ Freud $1 w t / w t: 1 A w t / f l x$. To obtain mice on the corresponding 5-HT1A wild-type (WT) background, TPH2-CreERT2-Freud-1wt/flx/1Awt/wt mice were bred to generate F1WT-1AWT mice.

\section{Genotyping}

Ear tissue samples were taken at 3 weeks of age and DNA extracted using the REDExtract-N-Amp Tissue PCR kit (Sigma). PCR was done using the following primers and conditions:
$C c 2 d 1 A^{f l x / f l x} .5^{\prime}$-TAG AAA CAC TTA CCC TCC ACA TTG-3' and 5'-TAG GAA GTG CCC ACC CAG A-3'. The PCR conditions were as follows: $94^{\circ} \mathrm{C}$ for $4 \mathrm{~min} ; 15$ cycles at $94^{\circ} \mathrm{C}$ for $30 \mathrm{~s}, 70^{\circ} \mathrm{C}$ for $30 \mathrm{~s}, 0.5^{\circ} \mathrm{C} /$ cycle, $72^{\circ} \mathrm{C}$ for $30 \mathrm{~s} ; 20$ cycles at $94^{\circ} \mathrm{C}$ for $30 \mathrm{~s}, 62^{\circ} \mathrm{C}$ for $30 \mathrm{~s}, 72^{\circ} \mathrm{C}$ for $30 \mathrm{~s}$; $62^{\circ} \mathrm{C}$ for $30 \mathrm{~s} ; 72^{\circ} \mathrm{C}$ for $10 \mathrm{~min}, 10^{\circ} \mathrm{C}$. This protocol results in $202 \mathrm{bp}$ (WT) and $382 \mathrm{bp}$ (floxed) products.

TPH2-CreERT2. TPH2-11679 5'-GCT GAG AAA GAA AAT TAC ATC G-3', CRE-125235'-TGG CTT GCA GGT ACA GGA GG-3', OIMR8744 5' -CAA ATG TTG CTT GTC TGG TG-3', and OIMR8745 $5^{\prime}$-GCT AGT CGA GTG CAC AGT TT- $3^{\prime}$. The PCR conditions were as follows: $94^{\circ} \mathrm{C}$ for $1 \mathrm{~min} ; 35$ cycles at $94^{\circ} \mathrm{C}$ for $15 \mathrm{~s}, 57^{\circ} \mathrm{C}$ for $20 \mathrm{~s}, 72^{\circ} \mathrm{C}$ for $10 \mathrm{~s} ; 94^{\circ} \mathrm{C}$ for $15 \mathrm{~s}, 72^{\circ} \mathrm{C}$ for $2 \mathrm{~min}, 10^{\circ} \mathrm{C}$. This protocol results in $200 \mathrm{bp}$ (WT) and $300 \mathrm{bp}$ (transgenic) products.

ROSA-YFP. OIMR4982 5'-AAG ACC GCG AAG AGT TTG TC-3', OIMR8545 5' -AAA GTC GCT CTG AGT TCT TAT-3', OIMR8546 5' GGA GCG GGA GAA ATG GAT ATG- $3^{\prime}$. The PCR conditions were as follows: $94^{\circ} \mathrm{C}$ for $3 \mathrm{~min}, 94^{\circ} \mathrm{C}$ for $30 \mathrm{~s}, 58^{\circ} \mathrm{C}$ for $1 \mathrm{~min}, 72^{\circ} \mathrm{C}$ for $1 \mathrm{~min}, 35$ cycles: $94^{\circ} \mathrm{C}$ for $30 \mathrm{~s}, 72^{\circ} \mathrm{C}$ for $10 \mathrm{~min}, 10^{\circ} \mathrm{C}$. This protocol results in 600 bp (WT) and $320 \mathrm{bp}$ (transgenic) products.

1Aflx/flx. 5'-GGG CGT CCT CTT CAC GTA G-3' and 5'-CAG GGA CGT TGT GGT GTT GT- $3^{\prime}$. The PCR conditions were as follows: $94^{\circ} \mathrm{C}$ for $2 \mathrm{~min}, 15$ cycles at $94^{\circ} \mathrm{C}$ for $30 \mathrm{~s}, 68^{\circ} \mathrm{C}$ for $30 \mathrm{~s}-0.5^{\circ} \mathrm{C} / \mathrm{cycle}, 68^{\circ} \mathrm{C}$ for $20 \mathrm{~s} ; 20$ cycles at $94^{\circ} \mathrm{C}$ for $30 \mathrm{~s}, 60^{\circ} \mathrm{C}$ for $30 \mathrm{~s}, 68^{\circ} \mathrm{C}$ for $20 \mathrm{~s} ; 60^{\circ} \mathrm{C}$ for $30 \mathrm{~s}$, $68^{\circ} \mathrm{C}$ for $5 \mathrm{~min}, 10^{\circ} \mathrm{C}$. This protocol results in $254 \mathrm{bp}(\mathrm{WT})$ and $292 \mathrm{bp}$ (floxed) products.

\section{Immunofluorescence}

Mice were anesthetized by lethal injection $(0.01 \mathrm{ml} / \mathrm{g}$, i.p. $)$ of sodium pentobarbital (Somnitol; MTC Pharmaceuticals) and perfused by cardiac infusion of $30 \mathrm{ml}$ PBS, then $25 \mathrm{ml} \mathrm{4 \%}$ PFA. Whole brains were isolated, cryoprotected overnight in $20 \%$ sucrose, and frozen at $-80^{\circ} \mathrm{C}$. Coronal brain slices $(20 \mu \mathrm{m})$ were prepared using the following coordinates: dorsal raphe (DR), bregma 4.36-4.72 mm (Paxinos and Franklin, 2001). Slices were thaw-mounted on Superfrost slides (ThermoFisher) and kept at $-80^{\circ} \mathrm{C}$. The sections were washed $3 \times$ in PBS, blocked $1 \mathrm{~h}$ in PBS with 1\% BSA, 10\% normal donkey serum, $0.1 \%$ Triton X-100 (or $0.3 \%$ Tween 20 for 5 -HT1A antibody), followed by overnight incubation at $22^{\circ} \mathrm{C}$ with chicken anti-GFP (Abcam, ab13970, 1:500; RRID: AB_300798), sheep anti-TPH (Millipore, ab1541 1:100; RRID: AB_90754), rabbit anti-5-HT1A receptor (custom made primary antibody raised to the i2 loop of the 5-HT1A receptor sequence; Cedarlane) (Czesak et al., 2012); rabbit anti-Freud-1, 1:1000 (Rogaeva and Albert, 2007); goat anti-5-HT (Abcam, ab66047, 1:500; RRID: AB_1142794); and rabbit anti-FosB (Santa Cruz Biotechnology, sc-48, 1:500; RRID:AB_631515). The sections were then washed three times in PBS and incubated for $1 \mathrm{~h}$ in secondary antibody at $22^{\circ} \mathrm{C}$. The secondary antibodies were as follows: AlexaFluor-488 anti-chicken (Jackson ImmunoResearch Laboratories, 103-545-155, 1:250; RRID:AB_2337390), antisheep Cy3 (Jackson ImmunoResearch Laboratories, 713-165-003, 1:200; RRID:AB_2340727), AlexaFluor-488 anti-rabbit (ThermoFisher, A-21206, 1:1000; RRID:AB_2535792), AlexaFluor-594 anti-rabbit (ThermoFisher, A-21207, 1:200; RRID:AB_141637), AlexaFluor-647 anti-goat (ThermoFisher, A-21447, 1:200; RRID:AB_2535864) in blocking solution. Images of DR were acquired with the Axiovision imaging software (RRID: SCR_002677) on a Zeiss Axio Observer D1 microscope under 10X and $20 \times$ magnification ( $n=4$ /group). Positive-stained cells were manually counted within a standardized template using ImageJ 1.48 version software; RRID:SCR_003070.

\section{5-HT1A autoradiography}

For autoradiography, mice were euthanized by cervical dislocation and decapitation. Extracted brains were frozen immediately on dry ice $\left(-75^{\circ} \mathrm{C}\right)$ and maintained at $-80^{\circ} \mathrm{C}$ until sectioning. Brains were cryosectioned at a thickness of $25 \mu \mathrm{m}$, and mounted sections were maintained at $-80^{\circ} \mathrm{C}$ until processing. Mounted sections were processed for ${ }^{125} \mathrm{I}$-MPPI (PerkinElmer) autoradiography as described previously (Donaldson et al., 2014; Luckhart et al., 2016). Sections were exposed to Kodak BioMax MR film (VWR) for $24 \mathrm{~h}$. Films were digitized at 1200 dpi resolution using an Epson Perfection V500 Photo Scanner, and signal density was measured 
using the mean luminosity function in ImageJ (1.49). Levels of 5-HT1A binding $(\mu \mathrm{Ci})$ were quantified by analyzing a standardized template outlining the region of interest, and adjacent background lacking specific binding subtracted. For raphe, data from sections at bregma -4.36 , $-4.48,-4.60,-4.72 \mathrm{~cm}$ were averaged; for hippocampus, bregma $-1.82 \mathrm{~cm}$ was used. Signals were within the linear range of the film and quantified based on standard curve using ARC146-F ${ }^{14} \mathrm{C}$ standard (American Radiochemicals).

\section{High performance liquid chromatography (HPLC) analysis}

Levels of 5-HT and 5-HIAA were quantified in extracts of dissected tissues by HPLC (Czesak et al., 2012). For HPLC, cF1ko and matched WT littermate mice ( $n=4,11$ weeks old) were killed by cervical dislocation and decapitation. The entire DR, hippocampus, and prefrontal cortex were dissected, pooled, frozen immediately on dry ice, and maintained at $-80^{\circ} \mathrm{C}$ until homogenization and analysis (Czesak et al., 2012). In brief, $300 \mu$ l of homogenization solution ( $0.3 \mathrm{~m}$ monochloroacetic acid, $0.1 \mathrm{~mm}$ EDTA, $10 \%$ methanol and internal standard) was added to each sample followed by sonication. Following sonication, $100 \mu \mathrm{l}$ was aliquoted and frozen for protein concentration determination (Pierce Coomassie Bradford Protein Assay). The remaining $200 \mu \mathrm{l}$ was centrifuged and the supernatant analyzed for 5-HT and 5-HIAA content using HPLC (Agilent Technologies). A $10 \mu \mathrm{l}$ volume of supernatant was injected via an autoinjector (1100 series Autosampler; Agilent) into the HPLC system equipped with an electrochemical detector (VT-03 flow cell, Intro detector; Antec Leyden) with an applied potential of $500 \mathrm{mV}$, a filter of $1 \mathrm{~s}$, and a range of $100 \mathrm{nA} / \mathrm{V}$. Separation of these analytes was achieved by their passage through a reverse-phase analytical column (Phenomenex Kinetex $2.6 \mu \mathrm{m} \mathrm{C}-18,100 \times 4.6 \mathrm{~mm}$ ). The column was equilibrated at a flow rate of $0.5 \mathrm{ml} / \mathrm{min}$ with mobile phase consisting of the following (in $\mathrm{mm}$ ): $90 \mathrm{NaH}_{2} \mathrm{PO}_{4}, 1.7$ 1-octane sulfonic acid (sodium salt), 50 citric acid (monohydrate), $5 \mathrm{KCl}, 50 \mathrm{EDTA}$, and $14 \%$ acetonitrile, final $\mathrm{pH}$ 3.0. The quantification of the analytes was performed by comparing their area under the curve with those of known external standards using the computerized ChemStation chromatography data acquisition system (Agilent).

\section{8-Hydroxy-2-(di-n-propylamino) tetralin (8OH-DPAT)-} induced hypothermia

The hypothermia procedure was performed from 9:00 to 11:00 A.M. Mice were weighed, and internal temperature was taken using a rectal thermometer every $10 \mathrm{~min}$ for $40 \mathrm{~min}$ ( 4 baseline measurements). Animals were administered $8 \mathrm{OH}$-DPAT $(0.75 \mathrm{mg} / \mathrm{kg}$, i.p., Sigma-Aldrich) followed by three measurements of basal body temperature at $10 \mathrm{~min}$ intervals. For analysis purposes, the first baseline temperature was discarded. The remaining three baseline values were averaged, and the difference between the average baseline and recorded temperature was plotted across time.

\section{Whole-cell electrophysiology}

Brainstem slices $(300 \mu \mathrm{m})$ containing the DR were prepared from 10- to 11-week-old mice as previously described (Geddes et al., 2016). In brief, mice were anesthetized and killed by decapitation. Once the brain was removed, coronal slices were made from a block of brain tissue while immersed in ice-cold cutting solution as follows (in mM): 119 choline-Cl, $2.5 \mathrm{KCl}, 1 \mathrm{CaCl}_{2}, 4.3 \mathrm{MgSO}_{4}-7 \mathrm{H}_{2} \mathrm{O}, 1 \mathrm{NaH}_{2} \mathrm{PO}_{4}, 1.30$ sodium L-ascorbate, $26.20 \mathrm{NaHCO}_{3}$, and 11 glucose at $37^{\circ} \mathrm{C}$ and equilibrated with $95 \% \mathrm{O}_{2} / 5 \% \mathrm{CO}_{2}$. Slices were then transferred to a recovery chamber containing standard Ringer's solution as follows (in $\mathrm{mM}$ ): $119 \mathrm{NaCl}, 2.5$ $\mathrm{CaCl}_{2}, 1.3 \mathrm{MgSO}_{4}-7 \mathrm{H}_{2} \mathrm{O}, 1 \mathrm{NaH}_{2} \mathrm{PO}_{4}, 26.2 \mathrm{NaHCO}_{3}$, and 11 glucose at $37^{\circ} \mathrm{C}$, bubbled with $95 / 5 \% \mathrm{O}_{2} / \mathrm{CO}_{2}$ and left to recover for $>1 \mathrm{~h}$ and equilibrated to room temperature $\left(\sim 25^{\circ} \mathrm{C}\right)$ before recordings. $\mathrm{DR}$ nucleus neurons were visualized using an upright microscope (Examiner D1; Zeiss) equipped with Dodt-gradient-contrast $(40 \times / 0.75$ NA objective). 5-HT neurons were identified by morphological and biophysical characteristics as previously established (Geddes et al., 2015). Whole-cell recordings performed at room temperature in standard Ringer's solution using borosilicate glass patch electrodes (3-6 $\mathrm{M} \Omega$; World Precision Instruments). 5-HT1A receptor-mediated currents were elicited by bath applying the 5-HT1A receptor agonist 5-carboxamidotryptamine (5-CT; $10 \mathrm{~nm}$; Tocris Bioscience) and holding current was monitored at $0.1 \mathrm{~Hz}$
$\left(V_{\mathrm{m}}=-55 \mathrm{mV}\right)$. These recordings were performed using an internal solution of the following composition (in $\mathrm{mM}$ ): 115 potassium gluconate, $20 \mathrm{KCl}, 10$ sodium phosphocreatine, $10 \mathrm{HEPES}, 4 \mathrm{Mg}^{2+}$-ATP, and 0.5 GTP (pH 7.25 adjusted with $\mathrm{KOH}$; osmolarity, $280-290 \mathrm{mOsmol} / \mathrm{L}$ ). Access resistance was continuously monitored by applying a $125 \mathrm{~ms}$, $2 \mathrm{mV}$ hyperpolarizing pulse every $10 \mathrm{~s}$, and recordings were discarded if the access resistance changed by $>30 \%$.

\section{Behavioral assays}

Behavioral tests were conducted in littermates starting 2 weeks after the last tamoxifen injection, at 11 weeks of age. Mice were housed under normal light conditions, and tests were performed beginning at 10:00 A.M., after at least $1 \mathrm{~h}$ of habituation to the testing room. Testing was performed under white light illumination, with the exception of the forced swim test (FST), which was performed under red light. All animals were of the same age at the start of testing, and all tests were done in the order below and completed within $10 \mathrm{~d}$. Each cohort included 10-32 mice/group. Throughout testing and behavioral analyses, the experimenter was blind to the mouse genotype.

\section{Elevated plus maze (EPM) test}

The mice were placed in the center of an elevated two-arm plus maze, measuring $\sim 20 \mathrm{~cm}$ high, $\sim 6 \mathrm{~cm}$ wide, and $\sim 75 \mathrm{~cm}$ long (Noldus, RRID: SCR_004074). The arms of the maze are crossed with one arm having an open platform, the other arm having a closed platform with walls that are $\sim 20 \mathrm{~cm}$ tall with overhead illumination (100-110 lux) and camera. Mice were placed in the center of the maze with the head toward the closed arm of maze and allowed to explore the maze for $10 \mathrm{~min}$. The mouse movements were videotaped, and the time spent in closed and open arms was determined (Ethovision 10, Noldus; RRID:SCR_000441).

\section{Open Field (OF) Test}

The mice were placed in a corner of the arena $(45 \mathrm{~cm}$ long in each side and $45 \mathrm{~cm}$ high) and allowed to explore the new environment for a total of $10 \mathrm{~min}$ at light levels of 300 lux. Mouse movements were videotaped and the time spent in the outside of a center $(24 \times 24 \mathrm{~cm})$ of the $\mathrm{OF}$ arena was analyzed (Ethovision 10, Noldus).

\section{Tail Suspension (TS) Test}

The tail of the mouse was secured with tape to a horizontal bar, and the animals were suspended for $6 \mathrm{~min}$ in mouse TS boxes (Med Associates). An automated detection device (ENV-505TS Load-Cell Amplifier) was used to determine mobility and immobility time through Med Associates software (Ethovision XT, Noldus).

\section{FST}

Each mouse was placed into clear plastic cylinder $22 \mathrm{~cm}$ in diameter and $37 \mathrm{~cm}$ deep filled with $4 \mathrm{~L}$ of water $\left(24^{\circ} \mathrm{C}\right)$. The mouse was videotaped from the side of the cylinder for 6 min under red light illumination, and the duration of immobility time was quantified using an automated video-tracking software from Med Associates (Ethovision XT).

\section{Novelty-Suppressed Feeding (NSF) Test}

The NSF test was used to assess anxiety-related behaviors (Santarelli et al., 2003). Briefly, animals were food deprived for $16 \mathrm{~h}$. After $3 \mathrm{~min}$ of habituation, they were placed in a new cage. Animals were individually placed in an arena ( $45 \mathrm{~cm}$ long in each side and $45 \mathrm{~cm}$ high; 300 lux) with a food pellet placed in the center. The latency of the mice to begin eating food was recorded manually and immediately after mice approached the food or after $10 \mathrm{~min}$ had expired for the trial, the mice were removed from the arena and placed in their home cage, and the latency to approach the food and the amount of food consumed in 5 min was measured.

\section{Beam Break (BBK) Test}

Mice were placed into a novel home cage for $30 \mathrm{~min}$. The home cage locomotor activity was measured by recording the number of breaks of invisible infrared light beams located on a frame surrounding the cage (Crawley, 2008) (Omnitech Electronics). 


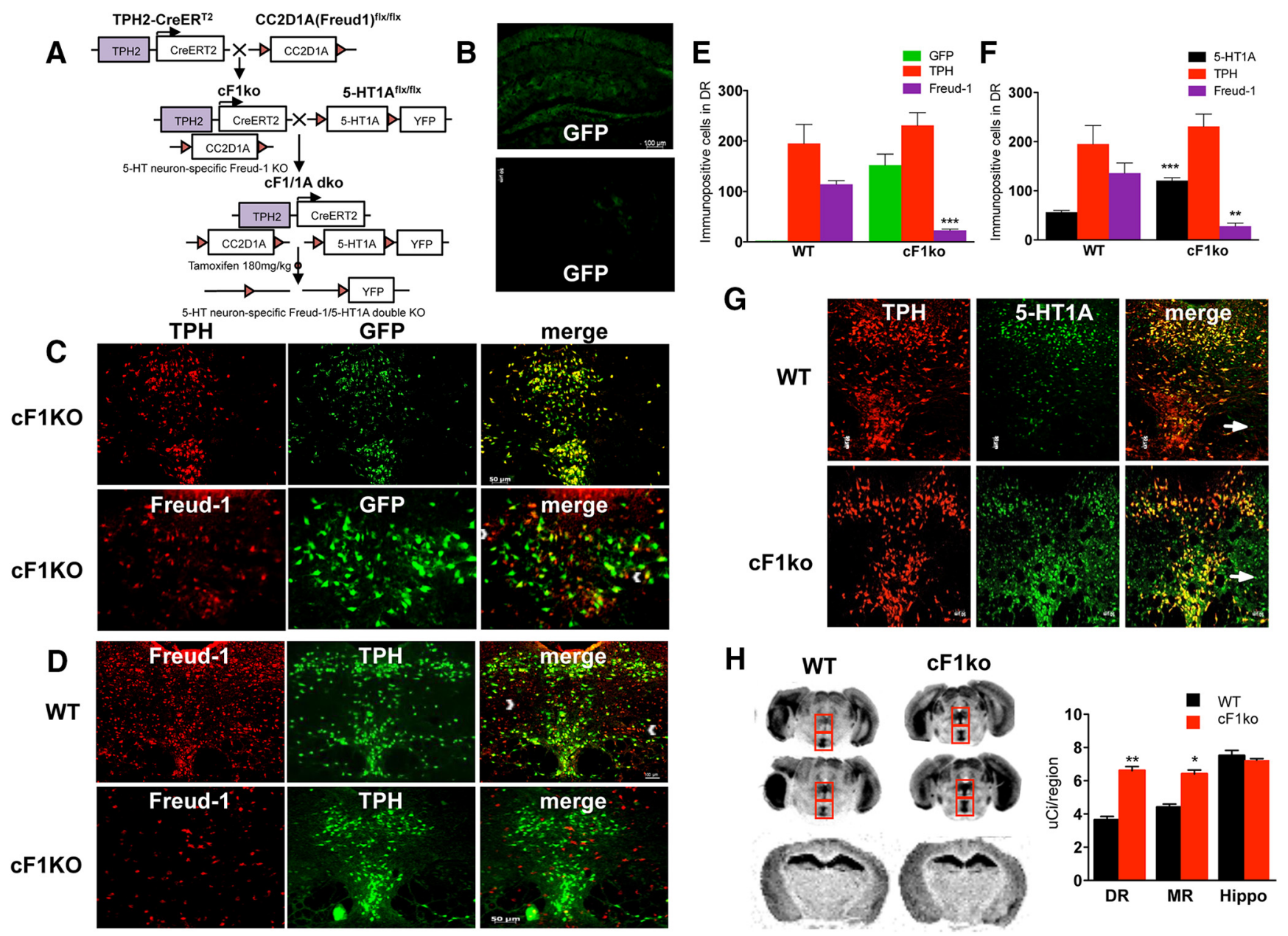

Figure 1. Loss of Freud-1 in 5-HT neurons increases 5-HT1A autoreceptors. A, Conditional K0 strategy. To delete Freud-1 in 5-HT neurons, the cF7ko mouse was generated by crossing C 2 d1a(Freud-1 $)^{f x / f f x}$ mice with TPH2-CreERT2 mice. At 8 weeks of age, mice were administered tamoxifen to activate CreERT2-induced recombination. To delete both Freud-1 and 5-HT1A autoreceptors in 5-HT neurons, the CF7ko mice were mated to the 5-HT1AflX/flx mice, in which the 5-HT1A gene is flanked by LoxP sites and a YFP cassette to generate the Freud-1/5-HT1A double KO mice following tamoxifen administration. B, Tamoxifen-induced recombination specificity. Hippocampal and prefrontal cortex sections from tamoxifen-treated conditional Freud- $1 \mathrm{KO} / \mathrm{ROSA}$-GFP mice (CF1KO) show background GFP staining. C, Tamoxifen-induced recombination and loss of Freud- 1 in DR. DR sections from tamoxifen-treated cF1KO mice were stained for GFP and either TPH or Freud-1 (10X magnification). Scale bar, $20 \mu \mathrm{m}$; inset, $20 \times$. GFP was present in $92 \%$ of TPH ${ }^{+}$cells, whereas $88 \%$ of Freud- 1 was in GFP ${ }^{-}$cells in cF1KO sections ( $\left.n=4\right)$. D, Loss of Freud-1 in 5-HT neurons. Freud-1/TPH-labeled cells in DR were almost absent in cF7ko compared with WT. By contrast, Freud-1 ${ }^{+} / \mathrm{TPH}^{-}$cells remained (white arrowheads) $(n=4)$. E, Quantification of GFP-, TPH-, and Freud-1-stained cells in DR of $c F 1 K O$ and WT mice $(n=4)$, shown as mean \pm SE $(p<0.001)$. $F$, Quantification of 5-HT1A-, TPH-, and Freud-1-stained cells in DR of $c F 1 k 0$ (non-ROSA-GFP) and WT mice $(n=4)$, shown as mean $\pm \mathrm{SE}(p<0.001)$. G, Loss of Freud- 1 and increased 5-HT1A ${ }^{+}$cells in DR of cF1ko mice. DR sections from tamoxifen-treated $c F 1 k 0$ versus F1wt (WT) mice (Scale bar, $50 \mu \mathrm{m} ; n=4$ ) were stained for TPH and 5-HT1A receptors (arrow, 5-HT1A in TPH ${ }^{-}$cells); 5-HT1A receptors were increased in TPH ${ }^{+}$cells. $\boldsymbol{H}$, Increased 5-HT1A binding in raphe of $\mathrm{cF} 1 \mathrm{ko}$ mice. Left, Representative images of ${ }^{125} \mathrm{I}-\mathrm{MPPI}$ autoradiography of sections from CF7 ko and WT mice in dorsal and median raphe (boxes) at two levels (bregma -4.60 and $-4.72 \mathrm{~mm}$ ) and hippocampus (bregma -1.70). Right, Quantification of ${ }^{125} \mathrm{I}-\mathrm{MPPI}$ binding. Data are mean \pm SEM $\left(n=4 /\right.$ group). ${ }^{*} p<0.05 .{ }^{* *} p<0.01 .5$-HT1A binding was increased in raphe of $c F 1 k 0$ mice: DR (unpaired two-tailed Student's $t$ test, $\mathrm{df}=6, t=9.129,{ }^{* * *} p<0.001$ ), MR (unpaired two-tailed Student's $t$ test, $\mathrm{df}=6, t=6.635,{ }^{*} p<0.05$ ).

Chronic selective serotonin reuptake inhibitor (SSRI) treatment For SSRI treatment, a separate cohort of mice, including conditional Freud-1 KO and WT littermates ( 11 weeks old, $n=10$ ), was single housed and received $18 \mathrm{mg} / \mathrm{kg} / \mathrm{d}$ fluoxetine (FLX) hydrochloride (Santarelli et al., 2003; Samuels et al., 2015) (Enzo Life Science, catalog \#BML-NS1400250) in drinking water for 3-4 weeks using opaque bottles to protect the SSRI from light. Then, several behavioral tests were done as described above, with ongoing SSRI treatment, following the timeline shown in Figure 4 . The consumption of FLX was measured accurately by weighing to determine the amount of drinking water consumed every $3 \mathrm{~d}(\sim 3$ $\mathrm{ml} / \mathrm{d}$ ) and did not differ between groups.

Statistical analyses

All analyses were done using the Statistical Package for the Social Sciences (Prism version 6.00 for Windows, GraphPad Software; www.graphpad. com; RRID:SCR_002798). Data are expressed as mean \pm SEM; $p \leq 0.05$ was used as the threshold for significance. Data comparing KO and WT littermates on one outcome measure were analyzed using unpaired $t$ test.
One-way ANOVA followed by Tukey's post-test was performed for multiple comparisons.

\section{Results}

Adult KO of Freud-1 in 5-HT neurons induces 5-HT1A autoreceptor upregulation

The $c$ F1 ko mice were generated for inducible KO of Freud- 1 in adult 5-HT neurons by crossing tamoxifen-inducible TPH2-CreERT2 and Cc2d1a (Freud-1) $)^{f l x / f l x}$ mice (Oaks et al., 2017) (Fig. 1A). Initially, to assess recombination specificity, $c F 1 k o$ mice were bred on a ROSA26-flxSTOP-GFP background ( $c F 1 K O)$. Tamoxifen injection in adulthood revealed that recombination to produce GFP was not detected in nonserotonergic regions that express 5-HT1A receptors, including the PFC and hippocampus (Fig. 1B). However, GFP was present in $92 \%$ of TPH $2^{+}$neurons in the raphe nuclei, and $100 \%$ of GFP-positive neurons were colocalized with TPH 
(Fig. 1C), indicating 5-HT neuron-specific recombination. Importantly, tamoxifen treatment of $c F 1 K O$ compared with $c F 1 w t$ mice strongly reduced the number of Freud $-1^{+}$cells (114 WT vs $22.5 c F 1 K O, t$ test, $\mathrm{df}=6, t=11.566, p=0.0022)$, with $\sim 90 \%$ of $\mathrm{GFP}^{+}$or $\mathrm{TPH}^{+}$raphe cells lacking Freud-1 (Fig. $1 C-F$ ). Freud-1 protein remained present in $\mathrm{TPH}^{-}$cells in the raphe (Fig. $1 C$, white arrowheads). In addition, there was no change in the number of $\mathrm{TPH}^{+}$cells, indicating that Freud-1 KO did not alter the number of 5-HT neurons (Fig. $1 E$ ). Thus, tamoxifen efficiently induces Freud-1 KO specifically in 5-HT neurons of the $c F 1 k o$ mice.

To identify changes in 5-HT1A autoreceptors upon KO of Freud-1 in 5-HT neurons, costaining of 5-HT1A receptors and $\mathrm{TPH}$ in the DR was examined (Fig. $1 G$ ). A significant increase in 5-HT1A-stained cells was observed in cF1ko compared with $c F 1 w t$ sections ( $t$ test, $\mathrm{df}=6, t=8.813, p=0.0001$ ) with no change in total $\mathrm{TPH}^{+}$cells (Fig. $1 F$ ). There was a significant increase in $5-\mathrm{HT} 1 \mathrm{~A} / \mathrm{TPH}$ costained cells (WT, $49.50 \pm 6.752$ vs $c F 1 k o, 132.3 \pm 10.10$ cells/template; $t$ test, $\mathrm{df}=6, t=6.810, p=$ 0.0005 ), with no change in $5-\mathrm{HT}_{1 \mathrm{~A} / \mathrm{TPH}^{-}}$cell count (Fig. $1 G$, arrows), indicating a specific upregulation of 5-HT1A autoreceptors upon Freud-1 KO in 5-HT neurons. In the $c F 1 k o$ raphe, we confirmed the reduction of Freud- ${ }^{+}$cells (Fig. 1F; WT, $135.8 \pm$ 20.95; cF1ko, $27.50 \pm 6.538$ cells/template; $t$ test, $\mathrm{df}=6, t=$ 4.933, $p=0.0026$ ). To further quantify the levels of 5-HT1A binding sites, autoradiography was performed using the selective 5-HT1A antagonist ${ }^{125}$ I-MPPI (Donaldson et al., 2014) and revealed a significant $>1.5$-fold increase in 5-HT1A binding in the dorsal and median raphe nuclei of $c F 1 k o$ versus $c F 1 w t$ mice, but similar levels of 5-HT1A binding in hippocampus (Fig. 1H). The 5-HT1A binding ( $\mu \mathrm{Ci} /$ region) was as follows: DR: $w t, 3.644 \pm 0.214$ versus $c F 1 k o, 6.609 \pm 0.244, t$ test, $\mathrm{df}=6, t=9.129, p=0.0001$; MR: $w t, 4.406 \pm 0.1895$ versus $c F 1 k o, 6.411 \pm 0.235, t$ test, $\mathrm{df}=6, t=$ $6.635, p=0.0006$; hippocampus, $w t, 7.509 \pm 0.318$ versus $c F 1 k o$, $7.245 \pm 0.086, t$ test, $\mathrm{df}=6, t=0.801, p=0.45$. In summary, consistent with its repressor function, loss of Freud-1 in 5-HT neurons results in a significant upregulation of 5-HT1A autoreceptors, whereas 5-HT1A heteroreceptor levels remain unchanged.

\section{Enhanced 5-HT1A function and reduced raphe 5-HT levels in cF1ko mice}

To determine the effect of Freud-1 deficiency on 5-HT1A autoreceptor function in vivo, we measured hypothermia in response to acute administration of the 5-HT1A agonist 8OH-DPAT, which in mice is dependent on 5-HT1A autoreceptor levels (Albert et al., 2014). Within $30 \mathrm{~min}, 0.75 \mathrm{mg} / \mathrm{kg} 8 \mathrm{OH}-\mathrm{DPAT}$ induced a maximal reduction in body temperature in the $c F 1 k o$ mice that was significantly greater than that in the $c F 1 w t$ mice and persisted for $70 \mathrm{~min}$, indicating an enhanced 5-HT1A autoreceptor response to the 5-HT1A agonist (Fig. 2A). To assess 5-HT1A autoreceptor function in single neurons, we performed wholecell voltage-clamp recordings from DR slices and bath-applied the 5-HT1A receptor agonist 5-CT (10 nM). The magnitude of 5-HT1A-mediated outward currents was similar in $c F 1 k o$ and F1wt mice (Fig. 2B), and similar results were obtained using 100 nм 5-CT (data not shown). Limitations of the slice preparation, including a lack of 5-HT autoinhibition or increased 5-CT induced internalization (Bouaziz et al., 2014; Andrade et al., 2015), could obscure the effect of 5-CT to produce increased response in the presence of excess 5-HT1A receptors.

Because 5-HT1A autoreceptors exert inhibitory tone on 5-HT neurons, we determined whether 5-HT levels are altered in $c F 1 k o$ mice. In $c F 1 k o$ compared with $c F 1 w t \mathrm{DR}$, there was a significant decrease $(\sim 50 \%)$ in 5-HT-positive cells from $68 \pm 10.5$ to $35 \pm$ 8.2 cells/template ( $t$ test, $\mathrm{df}=6 t=5.635, p=0.0013$ ), with no change in the number of $\mathrm{TPH}^{+}$cells (Fig. $2 C$ ). Similarly, quantitative measurement of 5-HT and its major metabolite 5-HIAA revealed an $\sim 50 \%$ reduction in raphe 5 -HT content in Freud- 1 KO versus WT mice ( $t$ test, $\mathrm{df}=4 t=6.375, p=0.0031$ ), with no significant change in raphe 5-HIAA or in hippocampal or PFC 5-HT or 5-HIAA levels (Fig. 2D). To address whether the activity of 5-HT neurons was changed, FosB staining was used as a marker for acute and chronic cellular activation. There was an $\sim 50 \%$ reduction in FosB/TPH-stained cells ( $49 \pm 11$ vs $25 \pm 7.9$ cells/template, $t$ test, $\mathrm{df}=6 t=4.035, p=0.0023)$ in the DR of cF1ko compared with F1wt mice, suggesting a chronic reduction of 5-HT neuronal activity. Together, these data indicate an upregulation of 5-HT1A autoreceptor expression and function upon loss of Freud-1 associated with increased autoinhibition of 5-HT neuron activity and reduced raphe 5-HT levels.

\section{FLX-resistant anxiety- and depression-like behavior in cF1ko mice}

The behavioral phenotype of adult $c F 1 k o$ mice was assessed using multiple validated tests (Fig. 3, timeline). Compared with F1wt littermates, $c F 1 k o$ mice displayed robust anxiety-like behavior in the EPM, OF, and NSF tests (Fig. $3 A-C$ ). In the EPM test, $c F 1 k o$ mice had a significant $50 \%$ reduction in time spent in the open arms, with no difference in total distance or closed arm time (Fig. $3 A$ ). In the OF test, $c F 1 k o$ mice spent significantly less time in the center of the arena and more time in the corners (Fig. 3B). In the NSF test, the $c F 1 k o$ mice displayed significantly greater latency to feed in the novel cage, whereas no difference was observed in latency for home cage food consumption (Fig. 3C). A depression-like phenotype was also detected in the $c F 1 k o$ mice, with increased immobility in the FST (Fig. $3 D)$ and a trend ( $p=0.07)$ in the TS test (Fig. $3 E$ ). No difference in open field locomotor activity was detected between $c F 1 k o$ and F1wt littermates in the BBK test (Fig. 3F). These results were confirmed in a second independent cohort of mice (data not shown). These data indicate that adult KO of Freud-1 in 5-HT neurons confers both anxiety- and depression-like phenotypes.

Increase in 5-HT1A autoreceptors is thought to reduce responsiveness to chronic SSRI treatment (Albert and François, 2010; Richardson-Jones et al., 2010). The behavioral response to FLX was tested in singly housed cF1 ko and F1wt littermates (11 weeks old, $n=10$ /group) treated or not with FLX in drinking water for 3-4 weeks using the above tests. In each test, the effect of conditional Freud-1 KO to increase anxiety/depression-like behavior was replicated. In the anxiety tests (EPM, OF, and NSF), chronic FLX treatment reduced anxiety-like behaviors in the $c F 1 w t$ mice but did not alter the anxiety phenotype in $c F 1 k o$ mice, compared with the vehicle-treated group (Fig. $4 A-C$ ), with no changes in control measures. Furthermore, the $c F 1 k o$ mice had increased immobility but showed no significant response to FLX in the FST, whereas the F1wt showed reduced immobility in FLX-treated versus vehicle (Fig. 4D). Neither $c F 1 k o$ nor F1wt mice showed any differences or response to FLX in the TS (Fig. $4 E$ ), or in the BBK test (Fig. $4 F$ ). These results indicate that the anxiety/depression-like phenotype seen in the $c F 1 k o$ mice and associated with overexpression of 5-HT1A autoreceptors is resistant to chronic FLX treatment.

\section{Requirement of 5-HT1A autoreceptors for Freud-1-dependent behavioral effects}

To address whether the behavioral phenotype induced by loss of Freud-1 is dependent on the increased level of 5-HT1A autore- 

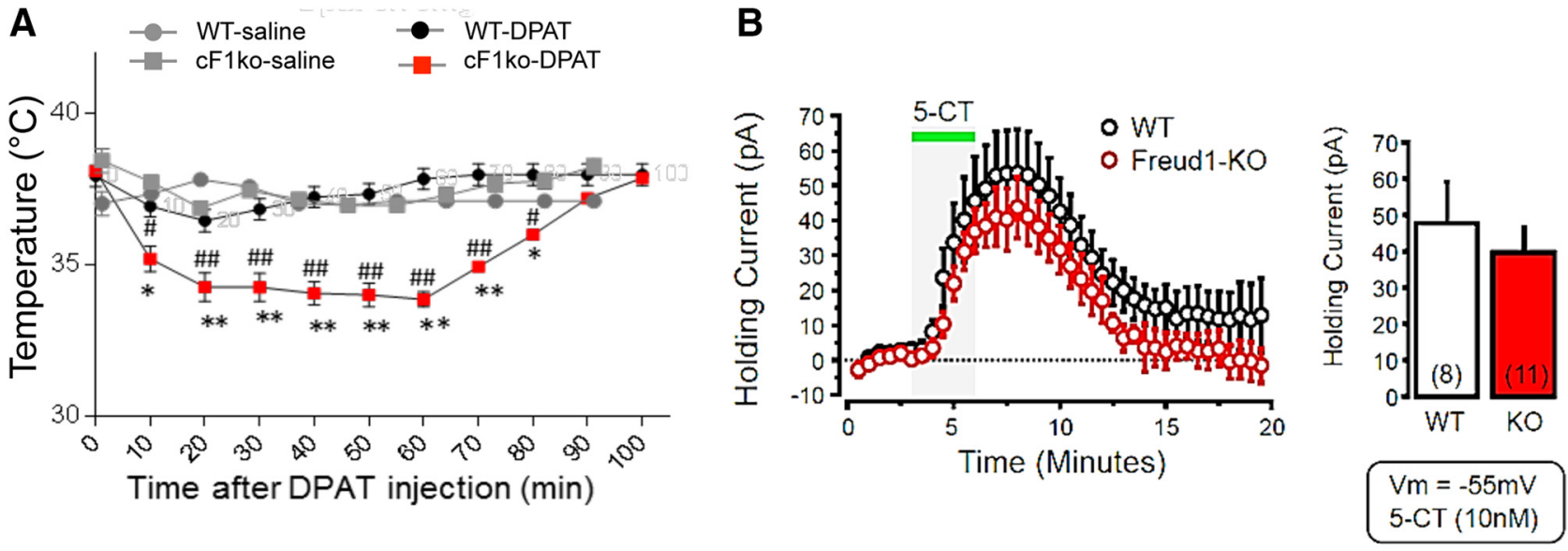

C
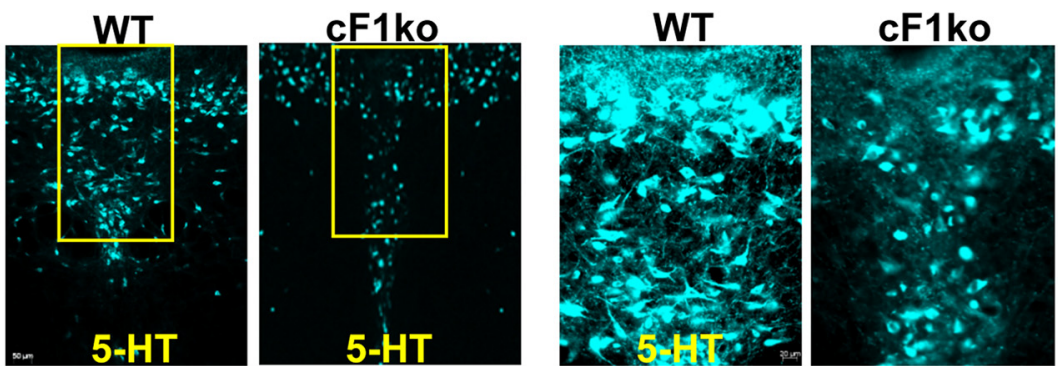

D
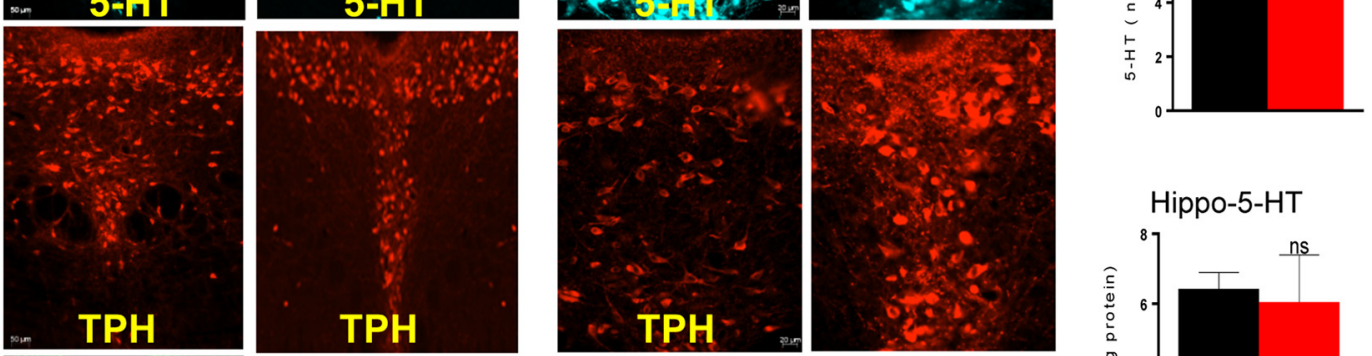

WT

cF1ko

PFC-5-HT

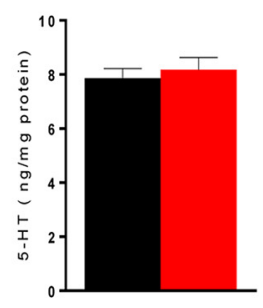

Hippo-5-HT

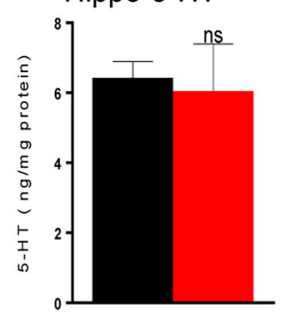

DR-5-HT

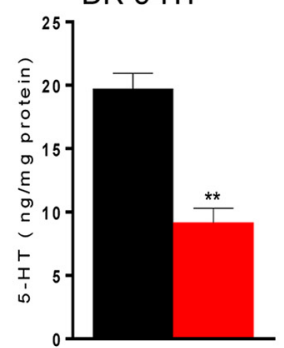

PFC-5-HIAA

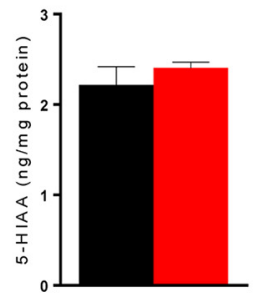

Hippo-5-HIAA

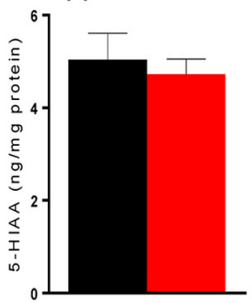

DR-5-HIAA

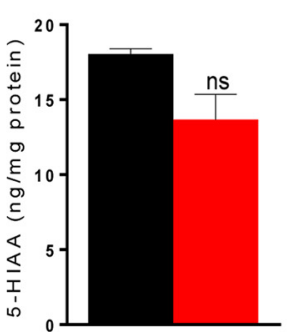

Figure 2. Loss of Freud-1 augments 5-HT1A autoreceptor function and reduces 5-HT neuron activity and 5-HT levels. A, 5-HT1A-induced hypothermia. 8-0H-DPAT (0.75 mg/kg, i.p.) induced a greater body temperature reduction in cF7ko compared with F1wt (WT). Data are mean \pm SEM $\left(n=3 /\right.$ group). ${ }^{*} p<0.05$ versus WT-saline. ${ }^{* *} p<0.001$ versus WT-DPAT. ${ }^{\#} p<0.05$ versus cF1ko-saline. ${ }^{\# \#} p<0.001$ versus CF1ko-DPAT. B, Whole-cell voltage-clamp recordings $\left(V_{\mathrm{m}}=-55 \mathrm{mV}\right)$ of 5 -HT neurons in slices of DR in vitro, from CF7ko or F1wt mice ( $\left.n=4\right)$ in response to 5 -CT $(10 \mathrm{~nm})$. No significant difference in 5-HT1A receptor-induced outward current was observed. C, Reduced 5-HT- and FosB-stained cells in $C$ F1ko raphe. DR sections of $c$ F 7 ko or F1wt (WT) mice stained for 5-HT, TPH, and FosB shown at $10 \times($ Scale bar: left, $50 \mu \mathrm{m}$ ) or $20 \times$ magnification of boxed region (Scale bar: right, $20 \mu \mathrm{m}$ ). D, Reduced raphe 5-HT content in CF1ko mice. Tissue 5-HT and 5-HIAA content was quantified by HPLC for DR, hippocampus (Hippo), and PFC of cF1ko versus WT mice. Data are mean \pm SEM ( $n=3 /$ group); reduced raphe 5 -HT content in cF1ko versus WT mice (unpaired two-tailed Student's $t$ test, $\mathrm{df}=4, t=6.675) .{ }^{* *} p<0.01$. 

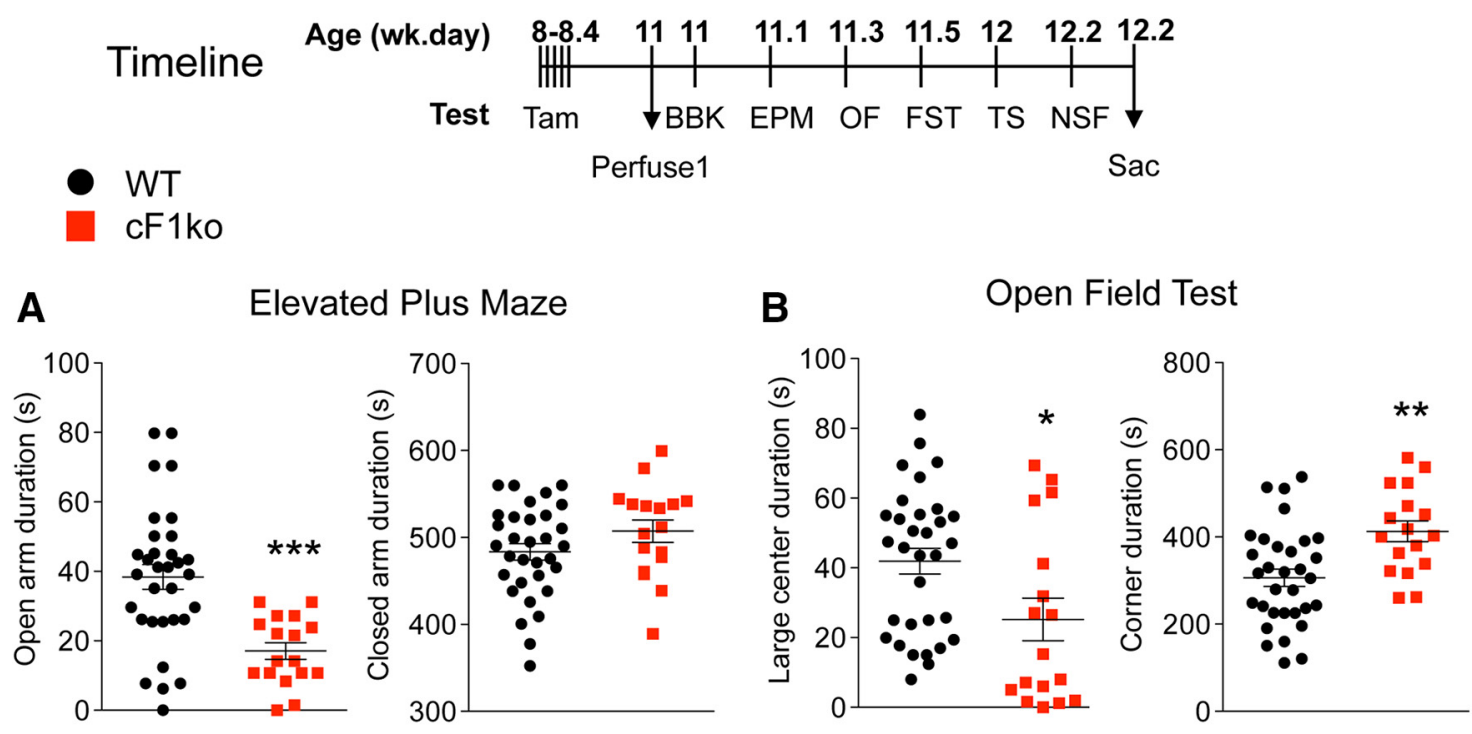

\section{C}

Novelty Suppressed Feeding
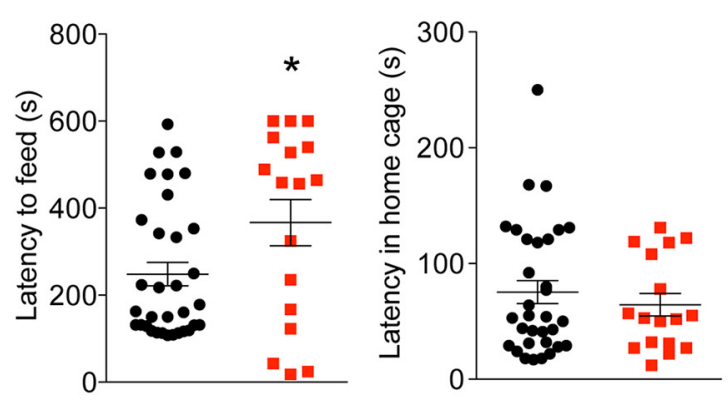

D Forced Swim Test

E Tail Suspension Test

F Beam-Break Test
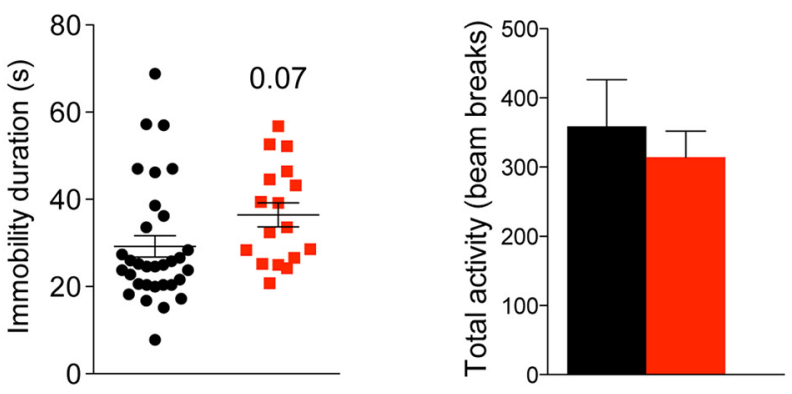

Figure 3. Increased anxiety- and depression-like behavior in CF7ko mice. The CFTko and WT littermates underwent the indicated behavioral tests or assays according to the timeline shown, 2 weeks after the last tamoxifen injection (11 weeks of age). $A-C$, Increased anxiety in CF1ko mice. A, EPM test. Compared with WT, cF1ko mice spent less time in open arms (unpaired two-tailed Student's $t$ test, $\mathrm{df}=47, t=4.104,{ }^{* *} p<0.01$ ), with no difference detected in closed arm time. $\boldsymbol{B}, 0 \mathrm{~F}$. cF 7 ko mice displayed significantly reduced distance traveled in large center (unpaired two-tailed Student's $t$ test, $\mathrm{df}=47, t=2.486,{ }^{*} p=0.0165$ ), with no change in total distance (data not shown). C, NSF test. CF7ko mice showed greater latency to approach food in the novel arena (unpaired two-tailed Student's $t$ test, $\mathrm{df}=48, t=2.221{ }^{*} p=0.0311$ ), but no difference in the home cage. $\boldsymbol{D}, \boldsymbol{E}$, Depression-like behavior in $C F 7 k$ mice. $\boldsymbol{D}$, FST. The cF7ko mice showed significant greater immobility duration in the FST compared with F1wt mice (unpaired two-tailed Student'st test, df $=47, t=2.962,{ }^{*} p<0.05$ ). E, TST. No difference in immobility duration between $c F 1 k 0$ and WT was seen. $\boldsymbol{F}$, Locomotion test. Results from the BBK test showed no difference in total 30 min activity comparing cF1ko and F1wt (WT) mice. Data are mean \pm SEM in cF1ko mice $(n=17)$ versus F1wt (WT) ( $n=32)$.

ceptors, the $c F 1 k o$ mice were mated to the $f l x-1 A$ mice (Samuels et al., 2015), in which the 5-HT1A gene is flanked by LoxP sites and a YFP cassette (Fig. 1A). Tamoxifen-induced recombination in 5 -HT neurons in $c F 1 / 1 A$ dko mice was verified by costaining for YFP and TPH (Fig. 5A). Staining for 5-HT1A receptors revealed a strong reduction in the number of $5-\mathrm{HT} 1 \mathrm{~A} / \mathrm{TPH}$-colabeled cells in cF1/1A dko compared with cF1ko/1Awt littermates (Fig. 5B; cF1ko/ $1 A w t, 120.5 \pm 6.19 ; c F 1 k o / 1 A k o, 16 \pm 2.48$ cells; $t$ test, $\mathrm{df}=6$, $t=15.650, p=0.0001)$. The presence of weak 5-HT1A staining in $\mathrm{TPH}^{-}$cells (Fig. 5B, white arrows) may represent 5-HT1A heteroreceptors in non-5-HT neurons of the raphe (Calizo et al., 2011). The extent of loss of 5-HT1A receptors in the $c F 1 / 1 \mathrm{~A} d k o$ mice was determined by autoradiography using the selective 5-HT1A antagonist ${ }^{125}$ I-MPPI. The results show significant reduction of 5 -HT1A binding in the dorsal $(6.327 \pm 0.40$ vs $1.339 \pm 0.1770 \mu \mathrm{Ci} ; t$ test, $\mathrm{df}=4, t=11.24, p=0.0004)$ and 


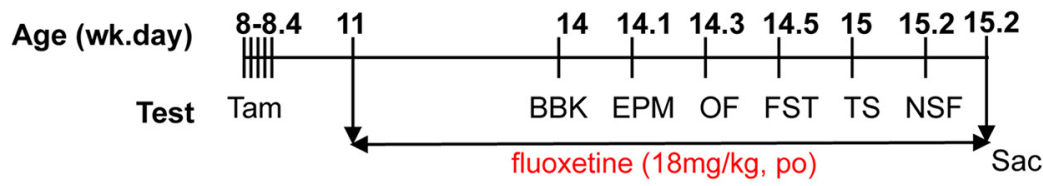

A

A Elevated Plus Maze

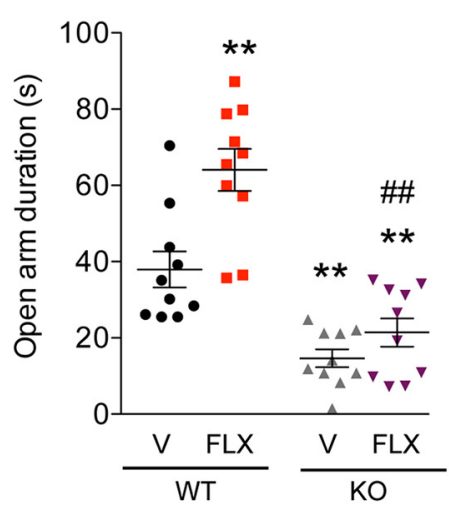

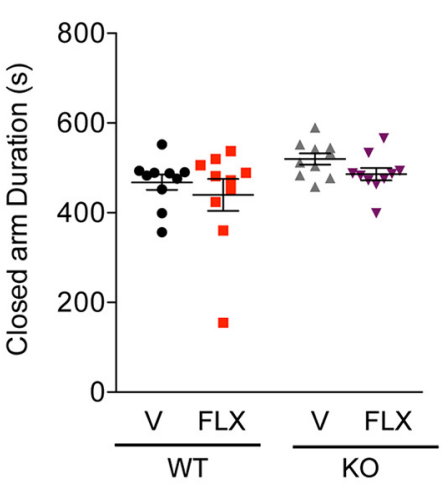

Novelty Suppressed Feeding

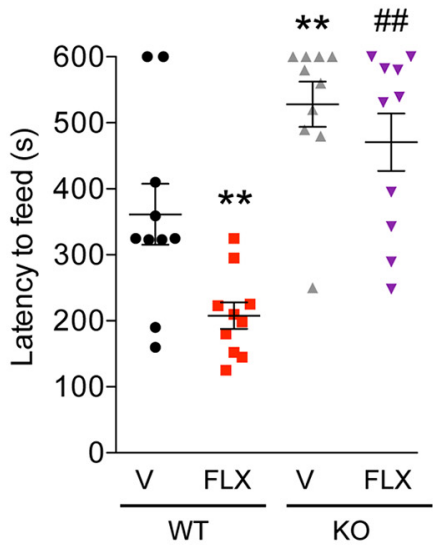

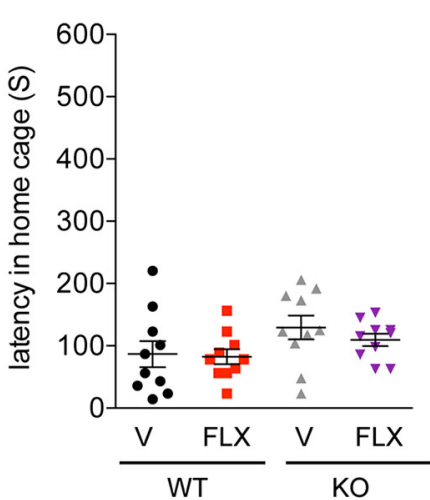

B

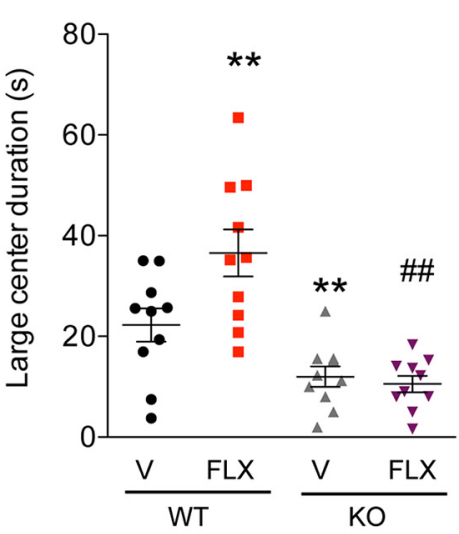

D Forced Swim Test

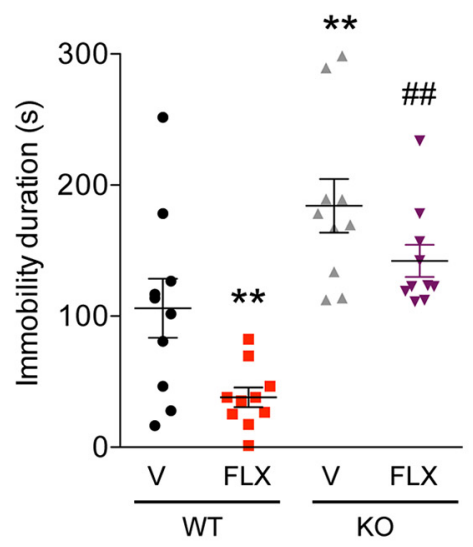

F Beam-Break Test

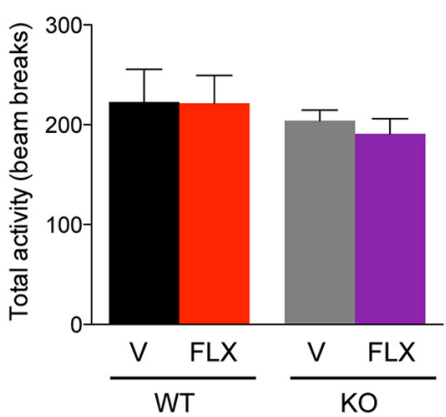

Figure 4. Resistance to chronic SSRI treatment in CF1ko mice. WT or CFIko (KO) mice were treated with FLX or vehicle (V) for 3 weeks and throughout the behavioral assays (timeline). $A-C$, Anxiety phenotype: chronic FLX reduced anxiety in WT mice but did not affect the increased anxiety seen in $C F 1$ ko mice. $A$, EPM, significant changes in time spent in open arms in EPM test (one-way ANOVA treatment $\times$ genotype interaction, $F_{(3,36)}=27.01, p<0.01$; post hoc Tukey). ${ }^{* *} p<0.01$ versus WT-V. ${ }^{\# \#} p<0.01$ versus WT-FLX. B, $0 F$, changes in distance traveled in large center (one-way ANOVA treatment $\times$ genotype interaction, $\left.F_{(3,36)}\right)=14.53, p<0.01$; post hoc Tukey). ${ }^{* *} p<0.01$ versus WT-V, ${ }^{\# \#} p<0.01$ versus WT-FLX. C, NSF, latency to approach food in novel arena (one-way ANOVA treatment $\times$ genotype interaction, $F_{(3,36)}=14.16, p<0.01$; post hoc Tukey). ${ }^{* *} p<0.01$ versus WT-V. ${ }^{\# \#} p<0.01$ versus WT-FLX. D, E, Depression phenotype. D, FST. Depression-like behavior in $C F 1 k o(V)$ compared with $F 1 w t(V)$ was indicated by increased immobility in the FST. Chronic FLX significantly reduced immobility in $F 1 w t$, but not in $c F 1 k o$ mice (one-way ANOVA treatment $\times$ genotype interaction, $F_{(3,36)}=13.62, p<0.01$; post hoc Tukey). ${ }^{* *} p<0.01$ versus WT-V. ${ }^{\# \#} p<0.01$ versus WT-FLX. $\boldsymbol{E}$, TST, no significant changes were observed. $\boldsymbol{F}$, BBK test. No differences in 30 min activity in novel arena were observed. Data represent individual animals with mean $\pm S E M ; n=10 /$ group. ${ }^{* *} p<0.01$ versus WT-V. ${ }^{\# \#} p<0.01$ versus WT-FLX. 
A

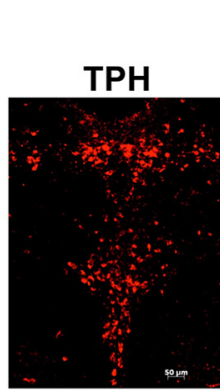

CF1/1A dKO

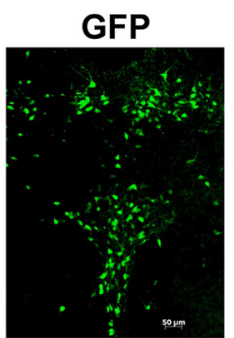

B
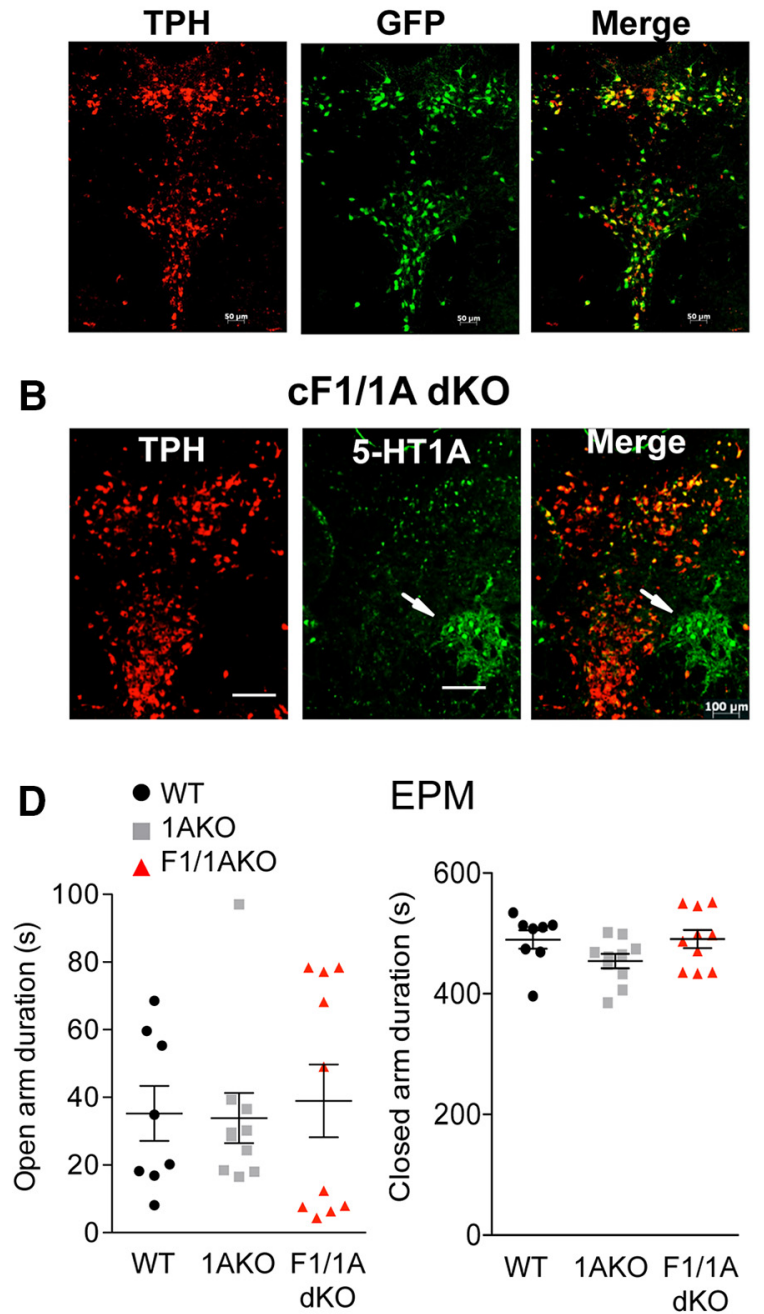

EPM

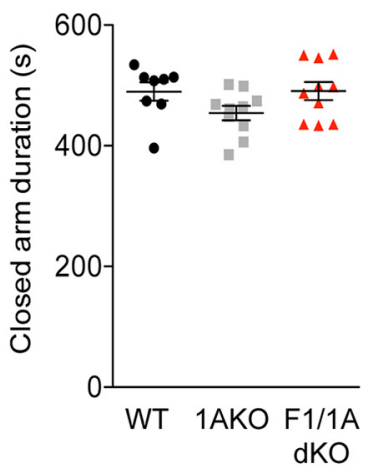

F

NSF

G
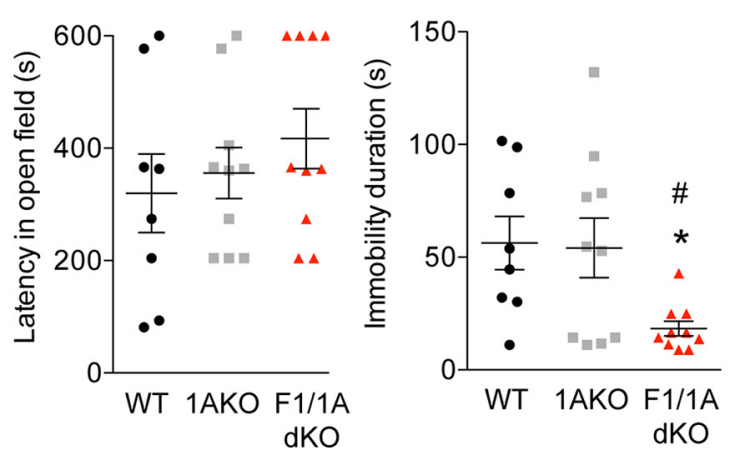

C
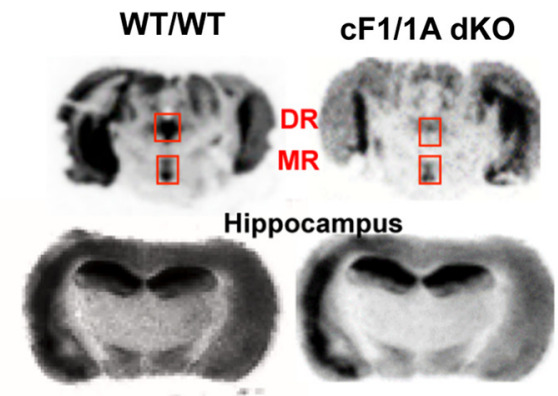

WTNT

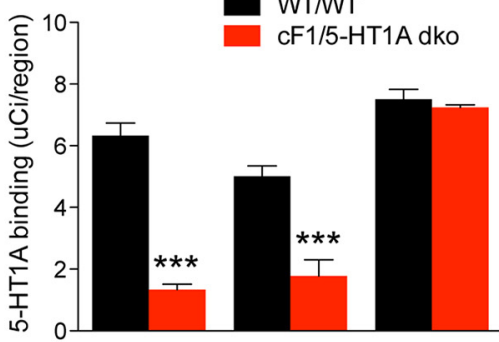

DRaphe MRaphe Hippo

E

OF
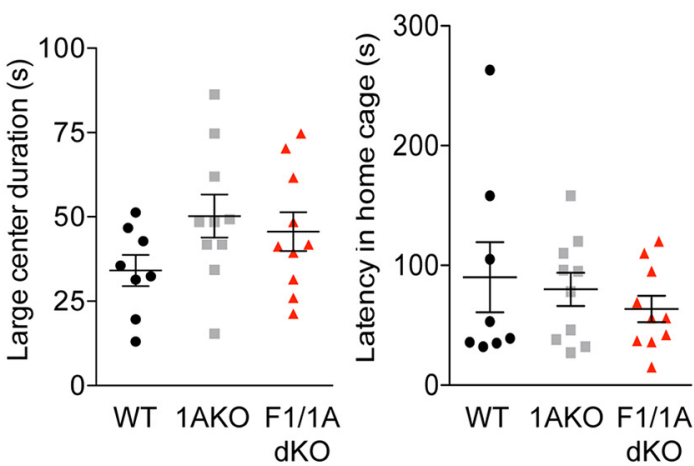

H

TS

I

BBK
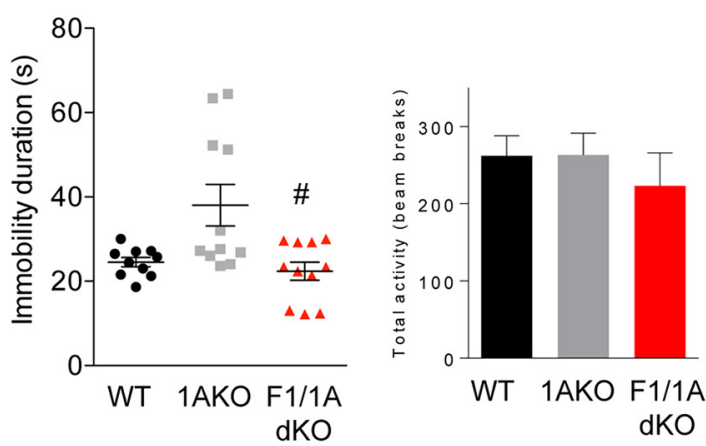

Figure 5. Reversal of anxiety- and depression-like phenotypes upon loss of Freud-1 in the absence of 5-HT1A autoreceptors. Tissues from mice with conditional $\mathrm{KO}$ of Freud-1 and 5-HT1A receptor in adult serotonin neurons (F1/1A dKO) were compared with 5-HT1A conditional KO (1AKO) or WT littermates (WT/WT). A, Tamoxifen-induced recombination. Costaining for YFP and TPH in the DR. Recombination occurred exclusively in 5 -HT cells; $92 \%$ of TPH ${ }^{+}$cells were YFP ${ }^{+}$. Scale bar, $100 \mu \mathrm{m}$. B, Loss of 5-HT1A autoreceptors. Immunostaining for 5-HT1A and TPH showed significant loss of 5-HT1A immunostaining in TPH ${ }^{+}$cells of $\mathrm{CF} 1 / 1 \mathrm{~A}$ dko mice. White arrows indicate the presence of 5-HT1A receptors in non-TPH ${ }^{+}$cells in DR. Scale bar, $100 \mu \mathrm{m}$. C, 5-HT1A autoradiography. 5-HT1A receptor autoradiography using ${ }^{125}$-MPPI of representative midbrain sections from WT/WT and CF1/1A dko mice, including dorsal (DR) and median (MR) raphe (boxes) and hippocampal sections. DR and MR showed significant decreases in 5-HT1A autoreceptor binding: DR (unpaired two-tailed Student's $t$ test, $\mathrm{df}=4, t=11.24,{ }^{* * *} p<0.001$ ), MR (unpaired two-tailed Student's $t$ test, $\left.\mathrm{df}=4, t=5.235,{ }^{* * *} p<0.001\right)$. D-H, Behavioral studies were done in either WT or conditional KO for Freud-1 (F1) and/or 5-HT1A receptor (1A) in littermate mice. D, EPM. No change in anxiety-like behavior (open arm time) was observed. $\boldsymbol{E}, 0$ F. No difference among groups was observed in time spent in the large center. $\boldsymbol{F}$, NSF. The latency to feed was not altered. G, FST. Immobility duration was reduced in F1/7A dKO versus WT and 1 AKO mice (one-way ANOVA genotype $\times$ genotype interaction, $F_{(2,25)}=4.463, p=0.0067 ;$ post hoc Tukey). ${ }^{*} p<0.05$ versus WT. ${ }^{\#} p<0.05$ versus 1AKO. $\boldsymbol{H}$, TS. Immobility time was reduced in F1/1AKO compared with WT or 1AKO (one-way ANOVA genotype $\times$ genotype interaction, $F_{(2,29)}=6.998, p=0.0033 ; p 0 s t$ hoc Tukey). " $p<$ 0.05 versus F1/1AKO. I, BBK test. No difference in 30 min activity in novel arena was observed. Data points represent individual mice, with mean \pm SEM: WT, $n=10 ; \mathrm{F} 1 \mathrm{WT} / 1 \mathrm{AK} 0, n=11 ; \mathrm{F} 1 / 1 \mathrm{AKO}$, $n=11$. 
median $(5.015 \pm 0.326$ vs $1.779 \pm 0.5248 \mu \mathrm{Ci} ; t$ test, $\mathrm{df}=4$, $t=5.235, p=0.0064$ ) raphe of $c F 1 / 1 A d k o$ (Fig. $5 C$ ). No difference in postsynaptic 5-HT1A receptor levels was observed in hippocampus of $c F 1 / 1 A d k o$ compared with $c F 1 k o / 1 A w t$ littermates. Thus, the $c F 1 / 1 \mathrm{~A} d k o$ mice show a significant reduction in the number of 5-HT1A autoreceptors.

The effect of Freud-1 KO on a 5-HT1A autoreceptor-negative background was examined using the $c F 1 / 1 A$ dko mice. In Freud-1 WT mice, $\mathrm{KO}$ of the 5-HT1A autoreceptor in adults (comparing $c F 1 w t / 1 A k o$ to $c F 1 w t / 1 A w t$ ) did not alter anxiety or depression behavior (Fig. $5 D-H$ ), consistent with previous results (RichardsonJones et al., 2010). In mice lacking 5-HT1A autoreceptors, there was no difference in anxiety behaviors between Freud-1 KO $(c F 1 / 1 A d k o)$ and WT $(c F 1 w t / 1 A k o)$ mice in the EPM, OF, or NSF tests, or in control measures (Fig. $5 D-F$ ). Surprisingly, although the KO of Freud-1 in the 5-HT1A WT background increased immobility in the FST, KO of Freud-1 in the 5-HT1A-KO background induced a stress resilient phenotype with reduced immobility in FST and TS compared with control groups ( $c F 1 w t / 1 A k o$ vs $c$ F1/1A $d k o$; Fig. $5 G, H$ ). Thus, the absence of 5-HT1A autoreceptors not only blocked the prodepressant effect of Freud-1 deletion, but unmasked an antidepressant-like effect. No significant change in locomotor activity among genotypes was observed in the beam-break test (Fig. 5I). Together, these results indicate that the anxiety/depression phenotype observed upon conditional KO of Freud-1 in 5-HT neurons depends on the presence of 5-HT1A autoreceptors.

\section{Discussion}

Freud-1 represses 5-HT1A autoreceptors to regulate 5-HT, anxiety, and depression

A reduction in 5-HT neurotransmission is implicated in anxiety and depression (Mann, 1999; Jans et al., 2007) and has been associated with increased 5-HT1A autoreceptor expression in depressed subjects (Parsey et al., 2010) and depressed suicides (Stockmeier et al., 1998; Boldrini et al., 2008). Thus, the transcriptional "set point" of 5-HT1A autoreceptor expression may be elevated in depression, suggesting altered function of transcription factors (Albert et al., 2011). Here we show that loss of Freud-1 in adult 5-HT neurons leads to upregulation of 5-HT1A autoreceptors (Fig. 1D-G) and is correlated with increased 5-HT1A response to DPAT-induced hypothermia (Fig. 2A), reduced raphe 5-HT levels (Fig. 2C,D), and anxiety/depression-like behaviors (Fig. 3) that are resistant to chronic SSRI treatment (Fig. 4). These findings implicate a key role for the endogenous repressor Freud-1 in 5-HT1A autoreceptor expression, leading to reduced raphe 5-HT and antidepressant-resistant anxiety and depression in the cF1ko mice. In contrast, global $\mathrm{KO}$ of the repressor Deaf1 resulted in upregulation of 5-HT1A autoreceptor expression, reduced raphe 5-HT, but only a mild anxiety phenotype (Czesak et al., 2012; Luckhart et al., 2016), consistent with a stronger effect of Freud-1 to repress the human 5-HT1A gene in raphe cells (Lemonde et al., 2003; Ou et al., 2003).

Previous studies have indirectly implicated transcriptional dysregulation of the human HTR1A gene in psychopathology and treatment resistance (Albert et al., 2011). For example, within the human HTR1A repressor region, a C(-1019)G polymorphism that prevents binding and repression by Deaf1/NUDR (Lemonde et al., 2003) has been associated with major depression and bipolar depression (Kishi et al., 2013), SSRI resistance (Le François et al., 2008; Kato et al., 2015; Takekita et al., 2015), and increased 5-HT1A autoreceptor levels in depressed subjects (Hesselgrave and Parsey, 2013). Allele-specific RT-PCR analysis has revealed that this polymorphism leads to lifelong alterations in 5-HT1A RNA levels in human PFC, which is attenuated in depressed subjects (Donaldson et al., 2016). Our finding of a major role for Freud-1 in repressing 5-HT1A autoreceptor expression and in SSRI-resistant anxiety/depression phenotype in mice is consistent with a key role for Freud-1-mediated repression in human anxiety and depression.

Importantly, we demonstrate that the behavioral effect of Freud-1 deletion is dependent on the presence of 5-HT1A autoreceptors in adult mice (Fig. 5). Previously, a mild (30\%) knockdown of the 5-HT1A autoreceptor in adulthood resulted in no change in anxiety or depression behaviors, but improved stress coping (Richardson-Jones et al., 2010), a phenotype that we did not assess in these studies. The antidepressed phenotype seen upon Freud-1 deletion when 5-HT1A autoreceptors are absent suggests that Freud-1 has a prodepressant effect that is revealed. Loss of Freud-1 in 5-HT1A-negative 5-HT neurons could alter the transcription of other genes, including derepressing dopamineD2 receptors (Rogaeva et al., 2007), which have been shown to increase 5-HT neuron activity (Aman et al., 2007), which in turn could lead to an antidepressant effect. We did not address whether other gene targets of Freud-1 contribute to behavioral outcomes in cF1ko mice, apart from increased 5-HT1A autoreceptor expression. In addition to 5-HT1A and dopamine-D2 gene repression, Freud-1 induces NF- $\kappa$ B expression (Matsuda et al., 2003; Zhao et al., 2010). Gene deletion of Freud-1 reduces NF- $\kappa$ B signaling to synaptic plasticity in cortical development, leading to abnormal cortical dendrite organization and reduced dendritic spine density (Manzini et al., 2014). However, these effects of Freud-1 deletion appear to be developmental, and deletion of Freud-1 in adulthood did not appear to affect neuronal organization (Oaks et al., 2017).

\section{SSRI resistance in Freud-1 conditional KO mice}

The 3 week latency for clinical efficacy of SSRI treatment is thought to involve desensitization of 5-HT1A autoreceptors to release 5-HT neurons from recurrent inhibition (Piñeyro and Blier, 1999; Albert et al., 2011). Our results suggest that loss of Freud-1 may render 5-HT neurons resistant to 5-HT1A receptor desensitization by chronic SSRI treatment. In human depression, increased 5-HT1A autoreceptors are correlated with resistance to SSRI treatment (Parsey et al., 2010). Furthermore, the G(-1019) allele associates with resistance to SSRI treatment (Lemonde et al., 2004b; Le François et al., 2008; Parsey et al., 2010). The HTR1A G-allele is also associated with resistance of negative symptoms to treatment with atypical antipsychotics that act in part by targeting 5-HT1A receptors (Reynolds et al., 2006; Newman-Tancredi and Albert, 2012). Together, these results implicate the increase in 5-HT1A autoreceptors upon loss of Freud-1 in resistance to chronic SSRI treatment. This resistance could suggest a role for activation of Freud-1 in desensitizing 5-HT1A autoreceptors in response to antidepressants. 5-HT1A receptors couple to inhibition of intracellular calcium levels (Albert et al., 1990; Penington et al., 1991), which could activate Freud-1 DNA binding and repression (Ou et al., 2003), leading to 5-HT1A autoreceptor desensitization. The loss of Freud-1 would prevent this process, leading to SSRI resistance. Alternately, the elevated levels of 5-HT1A autoreceptors may require high SSRI doses or longer times to fully desensitize. In this regard, 5-HT1A partial agonists or allosteric modulators that enhance Freud-1 signaling to desensitize presynaptic 5-HT1A receptors may prove useful to augment SSRI response in treatment-resistant subjects (Trivedi et al., 2006). The cF1ko mouse may provide a useful model to test novel antidepressants, 
such as ketamine, or deep brain stimulation for their dependence on 5-HT autoregulation, which has previously been examined using 5-HT depletion (Hamani et al., 2010; du Jardin et al., 2016).

\section{Roles of Freud-1 in vivo}

Our data suggest that susceptibility to anxiety and depression due to transcriptional dysregulation of the 5-HT1A receptor by Freud- 1 can be induced in adulthood and leads to reduced raphe 5-HT/5-HIAA level, suggesting a chronic reduction of 5-HT activity. Acute tryptophan depletion leads to relapse in recovered depressed but not control subjects, suggesting that depression confers increased susceptibility to 5-HT depletion. This could be due to persistent transcriptional dysregulation in recovered depressed subjects, as exemplified by the $c F 1 k o$ mice. Furthermore, patients that relapse often become more resistant to SSRI treatments, consistent with the SSRI-resistant phenotype of the $c F 1 k o$ mice, and suggesting a role for loss of Freud-1 function in the development of this resistance.

Disruption of the Cc2d1a/Freud-1 gene in humans is linked to non-syndromic intellectual disability and autism (BaselVanagaite et al., 2006; Manzini et al., 2014), conditions often associated with reduced social interaction. KO of Freud-1 in the postnatal mouse forebrain results in impaired cortical neuronal development, reduced cognitive function and social interaction, and anxiety-like behavior in the OF test (Oaks et al., 2017). This suggests that postsynaptic Freud-1 is also important for normal behavioral development. Consistent with this, Freud-1 levels are reduced in PFC following chronic stress in rats (Iyo et al., 2009), whereas both Freud-1 and 5-HT1A protein levels were reduced in PFC of young depressed subjects (Szewczyk et al., 2010), suggesting that early impairments in cortical Freud-1 levels may predispose to depression. The importance of presynaptic Freud-1 in 5-HT1A autoreceptor regulation and anxiety/depression behavior reported here and its complementary role in the forebrain in anxiety and cognitive function suggest that enhancing Freud-1 expression or function may provide a useful target, particularly in treatment-resistant forms of these diseases.

In conclusion, this study provides evidence that loss of Freud- 1 in 5-HT neurons causes overexpression of 5-HT1A autoreceptors, associated with SSRI-resistant and 5-HT1A autoreceptor-dependent anxiety/depression phenotypes and a 5-HT1A autoreceptor-inde pendent antidepressed phenotype, implicating Freud-1 as a key transcriptional regulator in 5-HT function and behavior.

\section{References}

Albert PR, Fiori LM (2014) Transcriptional dys-regulation in anxiety and major depression: 5-HT1A gene promoter architecture as a therapeutic opportunity. Curr Pharm Des 20:3738-3750. CrossRef Medline

Albert PR, François BL (2010) Modifying 5-HT1A receptor gene expression as a new target for antidepressant therapy. Front Neurosci 4:35. CrossRef Medline

Albert PR, Lemonde S (2004) 5-HT1A receptors, gene repression, and depression: guilt by association. Neuroscientist 10:575-593. CrossRef Medline

Albert PR, Zhou QY, Van Tol HH, Bunzow JR, Civelli O (1990) Cloning, functional expression, and mRNA tissue distribution of the rat 5-hydroxytryptamine1A receptor gene. J Biol Chem 265:5825-5832. Medline

Albert PR, Le François B, Millar AM (2011) Transcriptional dysregulation of 5-HT1A autoreceptors in mental illness. Mol Brain 4:21. CrossRef Medline

Albert PR, Vahid-Ansari F, Luckhart C (2014) Serotonin-prefrontal cortical circuitry in anxiety and depression phenotypes: pivotal role of pre- and post-synaptic 5-HT1A receptor expression. Front Behav Neurosci 8:199. CrossRef Medline

Aman TK, Shen RY, Haj-Dahmane S (2007) D2-like dopamine receptors depolarize dorsal raphe serotonin neurons through the activation of nonse- lective cationic conductance. J Pharmacol Exp Ther 320:376-385. CrossRef Medline

Andrade R, Huereca D, Lyons JG, Andrade EM, McGregor KM (2015) 5-HT1A receptor-mediated autoinhibition and the control of serotonergic cell firing. ACS Chem Neurosci 6:1110-1115. CrossRef Medline

Basel-Vanagaite L, Attia R, Yahav M, Ferland RJ, Anteki L, Walsh CA, Olender T, Straussberg R, Magal N, Taub E, Drasinover V, Alkelai A, Bercovich D, Rechavi G, Simon AJ, Shohat M (2006) The CC2D1A, a member of a new gene family with C2 domains, is involved in autosomal recessive non-syndromic mental retardation. J Med Genet 43:203-210. CrossRef Medline

Blier P, El Mansari M (2013) Serotonin and beyond: therapeutics for major depression. Philos Trans R Soc Lond B Biol Sci 368:20120536. CrossRef Medline

Boldrini M, Underwood MD, Mann JJ, Arango V (2008) Serotonin-1A autoreceptor binding in the dorsal raphe nucleus of depressed suicides. J Psychiatr Res 42:433-442. CrossRef Medline

Booij L, Tremblay RE, Szyf M, Benkelfat C (2015) Genetic and early environmental influences on the serotonin system: consequences for brain development and risk for psychopathology. J Psychiatry Neurosci 40:518. CrossRef Medline

Bouaziz E, Emerit MB, Vodjdani G, Gautheron V, Hamon M, Darmon M, Masson J (2014) Neuronal phenotype dependency of agonist-induced internalization of the 5-HT1A serotonin receptor. J Neurosci 34:282-294. CrossRef Medline

Calizo LH, Akanwa A, Ma X, Pan YZ, Lemos JC, Craige C, Heemstra LA, Beck SG (2011) Raphe serotonin neurons are not homogenous: electrophysiological, morphological and neurochemical evidence. Neuropharmacology 61:524-543. CrossRef Medline

Crawley JN (2008) Behavioral phenotyping strategies for mutant mice. Neuron 57:809-818. CrossRef Medline

Czesak M, Le François B, Millar AM, Deria M, Daigle M, Visvader JE, Anisman H, Albert PR (2012) Increased serotonin-1A (5-HT1A) autoreceptor expression and reduced raphe serotonin levels in deformed epidermal autoregulatory factor-1 (Deaf-1) gene knock-out mice. J Biol Chem 287: 6615-6627. CrossRef Medline

Donaldson ZR, Piel DA, Santos TL, Richardson-Jones J, Leonardo ED, Beck SG, Champagne FA, Hen R (2014) Developmental effects of serotonin $1 \mathrm{~A}$ autoreceptors on anxiety and social behavior. Neuropsychopharmacology 39:291-302. CrossRef Medline

Donaldson ZR, le François B, Santos TL, Almli LM, Boldrini M, Champagne FA, Arango V, Mann JJ, Stockmeier CA, Galfalvy H, Albert PR, Ressler KJ, Hen R (2016) The functional serotonin 1a receptor promoter polymorphism, rs6295, is associated with psychiatric illness and differences in transcription. Transl Psychiatry 6:e746. CrossRef Medline

du Jardin KG, Müller HK, Elfving B, Dale E, Wegener G, Sanchez C (2016) Potential involvement of serotonergic signaling in ketamine's antidepressant actions: a critical review. Prog Neuropsychopharmacol Biol Psychiatry 71:27-38. CrossRef Medline

Garcia-Garcia AL, Newman-Tancredi A, Leonardo ED (2014) 5-HT(1A) receptors in mood and anxiety: recent insights into autoreceptor versus heteroreceptor function. Psychopharmacology (Berl) 231:623-636. CrossRef Medline

Geddes SD, Assadzada S, Sokolovski A, Bergeron R, Haj-Dahmane S, Béïque JC (2015) Time-dependent modulation of glutamate synapses onto 5-HT neurons by antidepressant treatment. Neuropharmacology 95: 130-143. CrossRef Medline

Geddes SD, Assadzada S, Lemelin D, Sokolovski A, Bergeron R, Haj-Dahmane S, Béique JC (2016) Target-specific modulation of the descending prefrontal cortex inputs to the dorsal raphe nucleus by cannabinoids. Proc Natl Acad Sci U S A 113:5429-5434. CrossRef Medline

Hadjighassem MR, Austin MC, Szewczyk B, Daigle M, Stockmeier CA, Albert PR (2009) Human Freud-2/CC2D1B: a novel repressor of postsynaptic serotonin-1A receptor expression. Biol Psychiatry 66:214-222. CrossRef Medline

Hamani C, Diwan M, Macedo CE, Brandão ML, Shumake J, Gonzalez-Lima F, Raymond R, Lozano AM, Fletcher PJ, Nobrega JN (2010) Antidepressant-like effects of medial prefrontal cortex deep brain stimulation in rats. Biol Psychiatry 67:117-124. CrossRef Medline

Hesselgrave N, Parsey RV (2013) Imaging the serotonin 1A receptor using [11C]WAY100635 in healthy controls and major depression. Philos Trans R Soc Lond B Biol Sci 368:20120004. CrossRef Medline 
Iyo AH, Kieran N, Chandran A, Albert PR, Wicks I, Bissette G, Austin MC (2009) Differential regulation of the serotonin 1 A transcriptional modulators five prime repressor element under dual repression-1 and nucleardeformed epidermal autoregulatory factor by chronic stress. Neuroscience 163:1119-1127. CrossRef Medline

Jans LA, Riedel WJ, Markus CR, Blokland A (2007) Serotonergic vulnerability and depression: assumptions, experimental evidence and implications. Mol Psychiatry 12:522-543. CrossRef Medline

Kato M, Serretti A, Nonen S, Takekita Y, Wakeno M, Azuma J, Kinoshita T (2015) Genetic variants in combination with early partial improvement as a clinical utility predictor of treatment outcome in major depressive disorder: the result of two pooled RCTs. Transl Psychiatry 5:e513. CrossRef Medline

Kessler RC, Bromet EJ (2013) The epidemiology of depression across cultures. Annu Rev Public Health 34:119-138. CrossRef Medline

Kishi T, Yoshimura R, Fukuo Y, Okochi T, Matsunaga S, Umene-Nakano W, Nakamura J, Serretti A, Correll CU, Kane JM, Iwata N (2013) The serotonin $1 \mathrm{~A}$ receptor gene confer susceptibility to mood disorders: results from an extended meta-analysis of patients with major depression and bipolar disorder. Eur Arch Psychiatry Clin Neurosci 263:105-118. CrossRef Medline

Krishnan V, Nestler EJ (2008) The molecular neurobiology of depression. Nature 455:894-902. CrossRef Medline

Le François B, Czesak M, Steubl D, Albert PR (2008) Transcriptional regulation at a HTR1A polymorphism associated with mental illness. Neuropharmacology 55:977-985. CrossRef Medline

Lemonde S, Turecki G, Bakish D, Du L, Hrdina PD, Bown CD, Sequeira A, Kushwaha N, Morris SJ, Basak A, Ou XM, Albert PR (2003) Impaired repression at a 5-hydroxytryptamine $1 \mathrm{~A}$ receptor gene polymorphism associated with major depression and suicide. J Neurosci 23:8788-8799. Medline

Lemonde S, Rogaeva A, Albert PR (2004a) Cell type-dependent recruitment of trichostatin A-sensitive repression of the human 5-HT1A receptor gene. J Neurochem 88:857-868. CrossRef Medline

Lemonde S, Du L, Bakish D, Hrdina P, Albert PR (2004b) Association of the C(-1019)G 5-HT1A functional promoter polymorphism with antidepressant response. Int J Neuropsychopharmacol 7:501-506. CrossRef Medline

Luckhart C, Philippe TJ, Le François B, Vahid-Ansari F, Geddes SD, Beique JC, Lagace DC, Daigle M, Albert PR (2016) Sex-dependent adaptive changes in serotonin-1A autoreceptor function and anxiety in Deaf1deficient mice. Mol Brain 9:77. CrossRef Medline

Mann JJ (1999) Role of the serotonergic system in the pathogenesis of major depression and suicidal behavior. Neuropsychopharmacology 21 [Suppl 2]:99S-105S. CrossRef Medline

Manzini MC, Xiong L, Shaheen R, Tambunan DE, Di Costanzo S, Mitisalis V, Tischfield DJ, Cinquino A, Ghaziuddin M, Christian M, Jiang Q, Laurent S, Nanjiani ZA, Rasheed S, Hill RS, Lizarraga SB, Gleason D, Sabbagh D, Salih MA, Alkuraya FS, et al. (2014) CC2D1A regulates human intellectual and social function as well as NF-kappaB signaling homeostasis. Cell Rep 8:647-655. CrossRef Medline

Matsuda A, Suzuki Y, Honda G, Muramatsu S, Matsuzaki O, Nagano Y, Doi T, Shimotohno K, Harada T, Nishida E, Hayashi H, Sugano S (2003) Large-scale identification and characterization of human genes that activate NF-kappaB and MAPK signaling pathways. Oncogene 22:3307-3318. CrossRef Medline

Newman-Tancredi A, Albert PR (2012) Gene polymorphism at serotonin 5-HT1A receptors: moving towards personalized medicine for psychosis and mood deficits. In: Schizophrenia research: recent advances (Sumiyoshi T, ed), pp 337-358. New York: Nova.

Oaks AW, Zamarbide M, Tambunan DE, Santini E, Di Costanzo S, Pond HL, Johnson MW, Lin J, Gonzalez DM, Boehler JF, Wu GK, Klann E, Walsh CA, Manzini MC (2017) Cc2dla loss of function disrupts functional and morphological development in forebrain neurons leading to cognitive and social deficits. Cereb Cortex 27:1670-1685. CrossRef Medline

Ou XM, Jafar-Nejad H, Storring JM, Meng JH, Lemonde S, Albert PR (2000) Novel dual repressor elements for neuronal cell-specific transcription of the rat 5-HT1A receptor gene. J Biol Chem 275:8161-8168. CrossRef Medline

Ou XM, Lemonde S, Jafar-Nejad H, Bown CD, Goto A, Rogaeva A, Albert PR (2003) Freud-1: a novel calcium-regulated repressor of the 5-HT1A receptor gene. J Neurosci 23:7415-7425. Medline
Parsey RV, Ogden RT, Miller JM, Tin A, Hesselgrave N, Goldstein E, Mikhno A, Milak M, Zanderigo F, Sullivan GM, Oquendo MA, Mann JJ (2010) Higher serotonin 1A binding in a second major depression cohort: modeling and reference region considerations. Biol Psychiatry 68:170-178. CrossRef Medline

Paxinos G, Franklin KB (2001) The mouse brain in stereotaxic coordinates, Ed 2. San Diego: Academic.

Penington NJ, Kelly JS, Fox AP (1991) A study of the mechanism of $\mathrm{Ca}^{2+}$ current inhibition produced by serotonin in rat dorsal raphe neurons. J Neurosci 11:3594-3609. Medline

Piñeyro G, Blier P (1999) Autoregulation of serotonin neurons: role in antidepressant drug action. Pharmacol Rev 51:533-591. Medline

Reynolds GP, Arranz B, Templeman LA, Fertuzinhos S, San L (2006) Effect of 5-HT1A receptor gene polymorphism on negative and depressive symptom response to antipsychotic treatment of drug-naive psychotic patients. Am J Psychiatry 163:1826-1829. CrossRef Medline

Richardson-Jones JW, Craige CP, Guiard BP, Stephen A, Metzger KL, Kung HF, Gardier AM, Dranovsky A, David DJ, Beck SG, Hen R, Leonardo ED (2010) 5-HT(1A) Autoreceptor levels determine vulnerability to stress and response to antidepressants. Neuron 65:40-52. CrossRef Medline

Rogaeva A, Albert PR (2007) The mental retardation gene CC2D1A/ Freud-1 encodes a long isoform that binds conserved DNA elements to repress gene transcription. Eur J Neurosci 26:965-974. CrossRef Medline

Rogaeva A, Ou XM, Jafar-Nejad H, Lemonde S, Albert PR (2007) Differential repression by Freud-1/CC2D1A at a polymorphic site in the dopamine-D2 receptor gene. J Biol Chem 282:20897-20905. CrossRef Medline

Samuels BA, Anacker C, Hu A, Levinstein MR, Pickenhagen A, Tsetsenis T, Madroñal N, Donaldson ZR, Drew LJ, Dranovsky A, Gross CT, Tanaka KF, Hen R (2015) 5-HT1A receptors on mature dentate gyrus granule cells are critical for the antidepressant response. Nat Neurosci 18:16061616. CrossRef Medline

Santarelli L, Saxe M, Gross C, Surget A, Battaglia F, Dulawa S, Weisstaub N, Lee J, Duman R, Arancio O, Belzung C, Hen R (2003) Requirement of hippocampal neurogenesis for the behavioral effects of antidepressants. Science 301:805-809. CrossRef Medline

Stockmeier CA, Shapiro LA, Dilley GE, Kolli TN, Friedman L, Rajkowska G (1998) Increase in serotonin-1A autoreceptors in the midbrain of suicide victims with major depression-postmortem evidence for decreased serotonin activity. J Neurosci 18:7394-7401. Medline

Sullivan GM, Oquendo MA, Milak M, Miller JM, Burke A, Ogden RT, Parsey RV, Mann JJ (2015) Positron emission tomography quantification of serotonin $1 \mathrm{~A}$ receptor binding in suicide attempters with major depressive disorder. JAMA Psychiatry 72:169-178. CrossRef Medline

Szewczyk B, Albert PR, Rogaeva A, Fitzgibbon H, May WL, Rajkowska G, Miguel-Hidalgo JJ, Stockmeier CA, Woolverton WL, Kyle PB, Wang Z, Austin MC (2010) Decreased expression of Freud-1/CC2D1A, a transcriptional repressor of the 5-HT1A receptor, in the prefrontal cortex of subjects with major depression. Int J Neuropsychopharmacol 13:10891101. CrossRef Medline

Szewczyk B, Kotarska K, Daigle M, Misztak P, Sowa-Kucma M, Rafalo A, Curzytek K, Kubera M, Basta-Kaim A, Nowak G, Albert PR (2014) Stress-induced alterations in 5-HT1A receptor transcriptional modulators NUDR and Freud-1. Int J Neuropsychopharmacol 17:1763-1775. CrossRef Medline

Takekita Y, Fabbri C, Kato M, Nonen S, Sakai S, Sunada N, Koshikawa Y, Wakeno M, Okugawa G, Kinoshita T, Serretti A (2015) HTR1A gene polymorphisms and 5-HT1A receptor partial agonist antipsychotics efficacy in schizophrenia. J Clin Psychopharmacol 35:220-227. CrossRef Medline

Trivedi MH, Fava M, Wisniewski SR, Thase ME, Quitkin F, Warden D, Ritz L, Nierenberg AA, Lebowitz BD, Biggs MM, Luther JF, Shores-Wilson K, Rush AJ (2006) Medication augmentation after the failure of SSRIs for depression. N Engl J Med 354:1243-1252. CrossRef Medline

Whiteford HA, Degenhardt L, Rehm J, Baxter AJ, Ferrari AJ, Erskine HE, Charlson FJ, Norman RE, Flaxman AD, Johns N, Burstein R, Murray CJ, Vos T (2013) Global burden of disease attributable to mental and substance use disorders: findings from the Global Burden of Disease Study 2010. Lancet 382:1575-1586. CrossRef Medline

Zhao M, Li XD, Chen Z (2010) CC2D1A, a DM14 and C2 domain protein, activates NF-kappaB through the canonical pathway. J Biol Chem 285: 24372-24380. CrossRef Medline 